University of Massachusetts Amherst

ScholarWorks@UMass Amherst

Masters Theses

Dissertations and Theses

July 2016

\title{
Enzymatic Digestion Improved Bacteria Separation from Leafy Green Vegetables
}

Danhui Wang

University of Massachusetts Amherst

Follow this and additional works at: https://scholarworks.umass.edu/masters_theses_2

Part of the Food Microbiology Commons

\section{Recommended Citation}

Wang, Danhui, "Enzymatic Digestion Improved Bacteria Separation from Leafy Green Vegetables" (2016).

Masters Theses. 380.

https://doi.org/10.7275/8426105 https://scholarworks.umass.edu/masters_theses_2/380

This Open Access Thesis is brought to you for free and open access by the Dissertations and Theses at ScholarWorks@UMass Amherst. It has been accepted for inclusion in Masters Theses by an authorized administrator of ScholarWorks@UMass Amherst. For more information, please contact scholarworks@library.umass.edu. 


\section{ENZYMATIC DIGESTION IMPROVED BACTERIA SEPARATION FROM LEAFY GREEN VEGETABLES}

A Thesis Presented

by

DANHUI WANG

Submitted to the Graduate School of the University of Massachusetts Amherst in partial fulfillment of the requirements for the degree of

MASTER OF SCIENCE

MAY 2016

Food Science 
(C) Copyright by Danhui Wang 2016

All Rights Reserved 


\title{
ENZYMATIC DIGESTION IMPROVED BACTERIA SEPARATION FROM LEAFY GREEN VEGETABLES
}

\author{
A Thesis Presented \\ by \\ DANHUI WANG
}

Approved as to style and content by:

Sam R. Nugen, Chair

Julie M. Goddard, Member

Amanda J. Kinchla, Member

Eric Decker, Department Head

Food Science 


\section{DEDICATION}

To my parents, thank you very much for your love and support for my study and life. 


\section{ACKNOWLEDGMENTS}

I would like to thank my advisor, Professor Sam Nugen, for his guidance and oversight in this research project and the support throughout my degree. He helped me develop the independent study, critical thinking and important technical skills. I am also grateful for the helpful guidance and advice of Professor Amanda Kinchla on this project. I would also like to extend my gratitude to my committee members, Professors Sam Nugen, Julie Goddard and Amanda Kinchla. I am grateful for their helpful recommendations and valuable time.

A special thanks to the entire Bioengineering group. Thanks for the help from all the members past and present in the group. The friendship, collaboration, encouragement and advice have been my good memory. Thanks also goes to our past lab technician, Cynthia Kane, for her numerous lab orders. This work is supported by U.S. Department of Agriculture, National Institute of Food and Agriculture (USDA 2016-67017-24425), and the Center for Produce Safety (2015CPS11). 


\begin{abstract}
ENZYMATIC DIGESTION IMPROVED BACTERIA SEPARATION FROM LEAFY GREEN

VEGETABLES
\end{abstract}

May 2016

\title{
DANHUI WANG, B.S., EAST CHINA UNIVERSITY OF SCIENCE AND TECHNOLOGY M.S., UNIVERSITY OF MASSACHUSETTS AMHERST \\ Directed by: Professor Sam R. Nugen
}

An effective and rapid method for the separation of bacteria from food matrix remains a bottleneck for rapid bacteria detection for food safety. Bacteria can strongly attach to the food surface or internalize within the matrix which makes their isolation extremely difficult. Traditional methods of separating bacteria from foods routinely involve stomaching, blending and shaking, however these methods may not be efficient at removing all the bacteria from complex matrices. Here, we investigate the benefits of using enzyme digestion followed by immunomagnetic separation to isolate Salmonella from spinach and lettuce. Enzymatic digestion using pectinase and cellulase was able to break down the structure of the leafy green vegetables resulting in the detachment and release of Salmonella from the leaves. Immunomagnetic separation of Salmonella from the liquefied sample allowed an additional separation step to achieve a more pure sample without leaves debris that may benefit additional downstream applications. We have investigated the optimal combination of pectinase and cellulase for the digestion of spinach and lettuce to improve sample detection yields. The concentrations of enzymes used to digest the leaves were confirmed to have no significant effect on the viability of the inoculated Salmonella. Results reported that the recovery of the Salmonella from the produce after enzyme digestion of the leaves was significantly higher $(\mathrm{P}<0.05)$ than traditional sample preparation methods to separate bacteria (stomaching and manually shaking). The results 
demonstrate the potential for use of enzyme digestion prior to separation can improve the efficiency of bacteria separation and increase the likelihood of detecting pathogens in the final detection assay. 


\section{TABLE OF CONTENTS}

ACKNOWLEDGMENTS $\mathrm{V}$

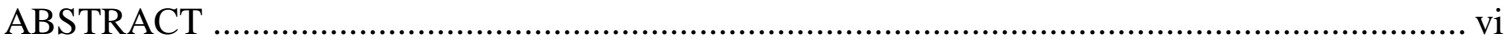

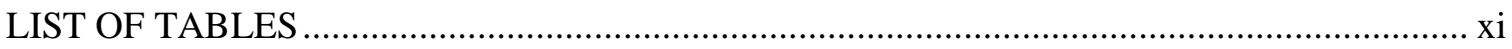

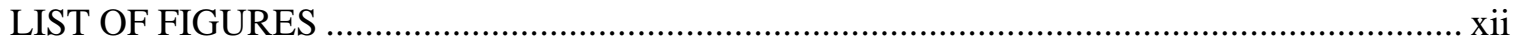

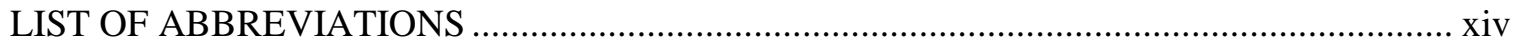

CHAPTER

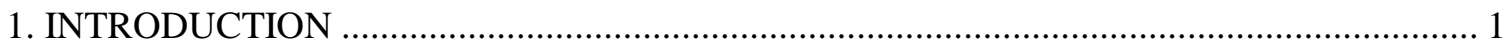

2. BACTERIA CONCENTRATION AND SEPARATION AND THE OBSTACLES OF

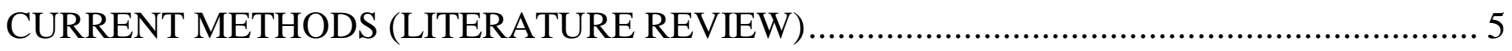

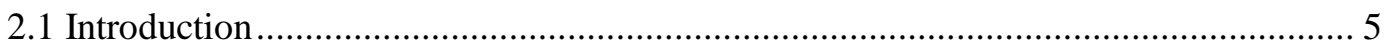

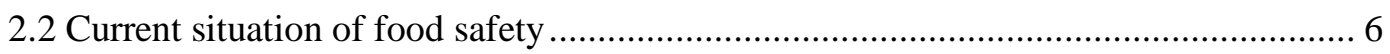

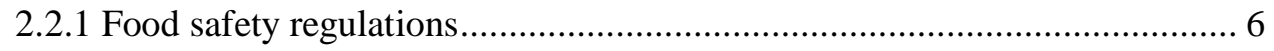

2.2.2 Foodborne pathogen and foodborne diseases ....................................... 6

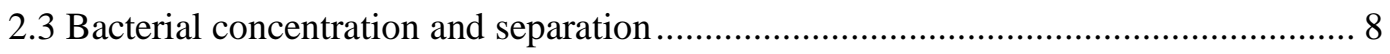

2.3.1 Bacterial separation from the solid food matrix ........................................ 9

2.3.1.1 Principle of bacterial attachment on the solid food sample .......... 9

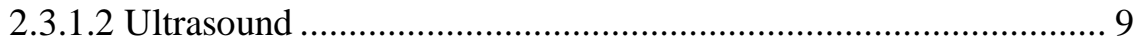

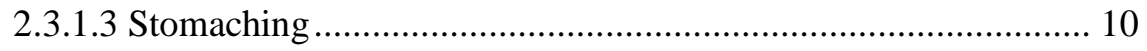

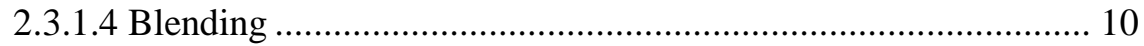

2.3.2 Bacterial separation from the liquid food matrix ................................... 11

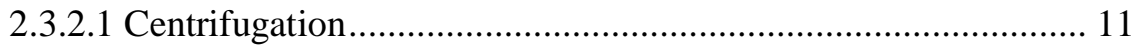

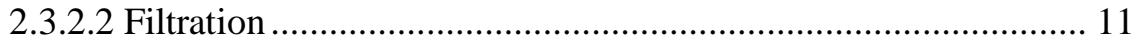

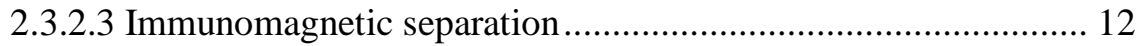


2.4 The obstacles of the current separation methods ................................................. 14

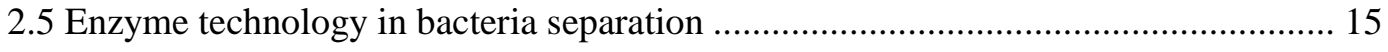

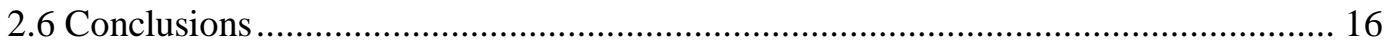

3. OPTIMIZATION OF THE CONDITIONS FOR ENZYMATIC DIGESTION ...................... 18

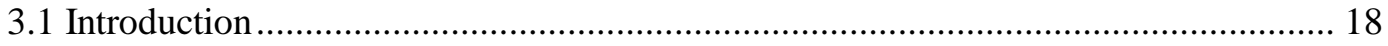

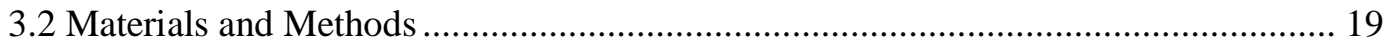

3.2.1 Optimization of the enzyme conditions ................................................. 19

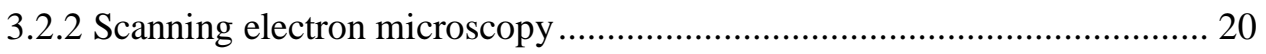

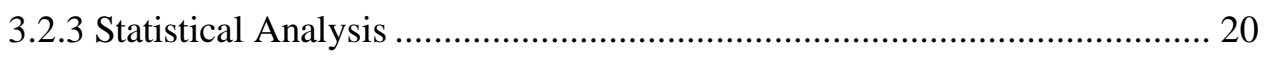

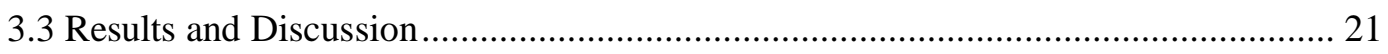

3.3.1 Optimization of the $\mathrm{pH}$ and time of the enzymatic digestion ................... 21

3.3.2 Optimization of the concentration of the enzymatic digestion .................. 23

3.3.3 Physical appearance and SEM evaluation of enzymatic digestion............ 25

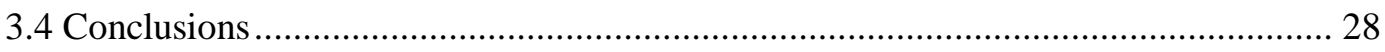

4. SALMONELLA RECOVERY AFTER ENZYMATIC DIGESTION AND THE COMPARISON WITH STOMACHING AND MANUALLY SHAKING .............................. 30

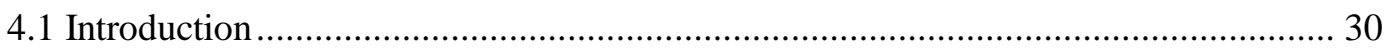

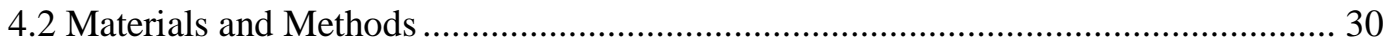

4.2.1 Preparation of inocula...................................................................... 30

4.2.2 Salmonella viability study ….............................................................. 31

4.2.3 Inoculation of the produce and sample preparation ................................ 31

4.2.4 Immunomagnetic separation and microbiological studies ...................... 32

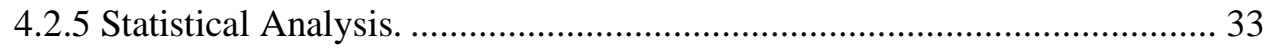

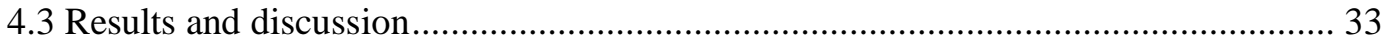


4.3.1 The effect of enzyme on the viability of Salmonella

\subsubsection{Salmonella recovery on spinach and lettuce after enzymatic}

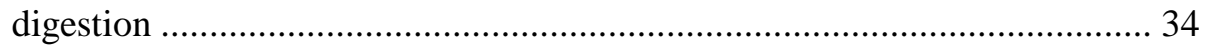

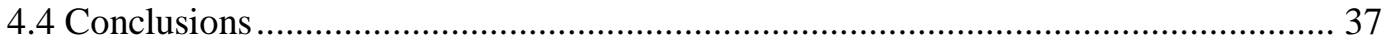

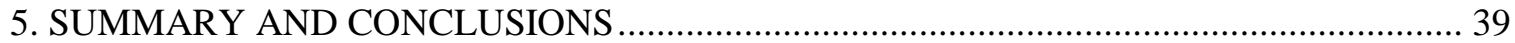

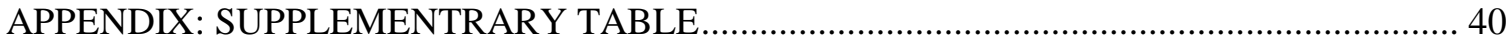

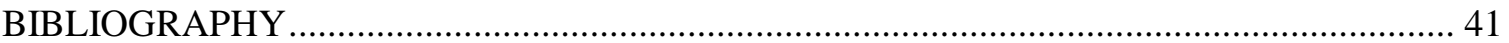




\section{LIST OF TABLES}

Table

Page

1 The combinations of pectinase and cellulase used for the digestion of lettuce and spinach, respectively. The enzymes were aimed to digest $10 \mathrm{~g}$ of leaves in $90 \mathrm{~mL}$ PBS buffer........... 40 


\section{LIST OF FIGURES}

Figure

1.1 Schematic representation of the separation of Salmonella from the spinach using enzymatic digestion with pectinase and cellulase followed by immunomagnetic separation and plate counting. (a) Spot inoculation of Salmonella on the surface of spinach. (b) Enzymatic digestion of spinach at $37^{\circ} \mathrm{C}$ for 1.5 hours. (c) Immunomagnetic separation of the liquefied sample after enzymatic digestion. (d) Plating on HE agar followed by enumeration.

2.1 Schematic of food microbiological analysis (Source: Brehm-Stecher et al, 2009) (6)......

3.1 The results of enzymatic digestion of lettuce and spinach in $2 \times$ PBS buffer with pH 7.0 and $\mathrm{pH} 7.5$, respectively. The white bars with oblique lines represent the digestion results using PBS buffer with $\mathrm{pH} 7.0$ and the grey bars represent the digestion results using PBS buffer with $\mathrm{pH}$ 7.5. Bars with same letter are not significantly different $(\mathrm{P}>0.05)$ between $\mathrm{pH} 7.0$ and $\mathrm{pH} 7.5$.

3.2 The percentage of enzymatic digestion of lettuce (solid line) and spinach (dotted line) after incubation for $0,0.5,1.0,1.5,2.0$ hours at $37^{\circ} \mathrm{C}$. The enzymes used for lettuce were $10.0 \mathrm{U} / \mathrm{g}$ pectinase, $10.0 \mathrm{U} / \mathrm{g}$ cellulase and the combination of $5.0 \mathrm{U} / \mathrm{g}$ pectinase and $5.0 \mathrm{U} / \mathrm{g}$ cellulase, respectively. The enzymes used for spinach were $30.0 \mathrm{U} / \mathrm{g}$ pectinase, $30.0 \mathrm{U} / \mathrm{g}$ cellulase and the combination of $15.0 \mathrm{U} / \mathrm{g}$ pectinase and $15.0 \mathrm{U} / \mathrm{g}$ cellulase, respectively

3.3 The digestion percentage of the leaves of (a) (c) lettuce and (b) (d) spinach, respectively. The results were obtained after digestion using varying concentrations of pectinase (a) or cellulase (b) in the buffer with $\mathrm{pH} 7.0$ and the combination of the enzymes (c) (d) in the buffer with $\mathrm{pH} 7.4$ for 1.5 hours at $37{ }^{\circ} \mathrm{C}$ and after filtration. In each panel bars with same letter $(\mathrm{a}$ or $\mathrm{b})$ are not significantly different $(\mathrm{P}>0.05)$ among varying combinations of enzymes.

3.4 The physical appearance of the leaves of lettuce (a) (c) and spinach (e) (g) before the incubation. The physical appearance of the leaves of the lettuce (b) and spinach (f) without enzyme digestion and lettuce (d) and spinach (h) with enzyme digestion after $10 \mathrm{~s}$ of mixing and 1.5 hours of incubation. The concentration of the enzyme used was $7.5 \mathrm{U} / \mathrm{g}$ pectinase and $2.5 \mathrm{U} / \mathrm{g}$ cellulase for lettuce and $22.5 \mathrm{U} / \mathrm{g}$ pectinase and $7.5 \mathrm{U} / \mathrm{g}$ cellulase for spinach.

3.5 Scanning electron micrograph of the leaf surfaces of the lettuce before (a) and after (b) enzymatic digestion. Scanning electron micrograph of the leaf surfaces of the spinach before (c) and after (d) enzymatic digestion. The samples were treated with pectinase and cellulase and mixed for 10s followed by incubation of 1.5 hours. 
4.1 The number of Salmonella inoculated in $2 \times$ PBS (pH 7.4) with the combination of enzyme used to digest lettuce or spinach as well as the control (no enzyme) after incubation of 1.5 hours at $37^{\circ} \mathrm{C}$. Bars with same letter are not significantly different $(\mathrm{P}>0.05)$. The error bars represent the standard deviation of three measurements............. 3

4.2 The recovery of the Salmonella separated from the lettuce and spinach, respectively after three different separation methods of bacteria. The white bar represents the recovery of Salmonella after homogenization of $10 \mathrm{~s}$ and enzymatic digestion for 1.5 hours. The grey bars represent the recovery of Salmonella after stomaching for 1 minute. The white bars with oblique lines represent the recovery of Salmonella after manually shaking. Bars with different letters $(\mathrm{a}, \mathrm{b}$ or $\mathrm{c})$ are significantly different $(\mathrm{P}<0.05)$ among the groups. 


\section{LIST OF ABBREVIATIONS}

U.S. FDA - United States Food and Drug Administration

USDA - United States Department of Agriculture

WHO - World Health Organization

CDC - Centers for Disease Control and Prevention

CSPI - Center for Science in the Public Interest

BAM - Bacteriological Analytical Manual

IMS - Immunomagnetic separation

PBS - Phosphate buffered saline

TSB - Tryptone soya broth

HE agar - Hektoen enteric agar

SEM - Scanning electron microscope 


\section{CHAPTER 1}

\section{INTRODUCTION}

Food safety remains a serious health concern in both developing and industrialized nations $(36,53)$. In order to better ensure the safety of food, a combination of mitigation strategies including prevention, detection and validation must be followed to reduce the risk of foodborne illness. The Bacteriological Analytical Manual from the U.S. Food and Drug Administration (FDA) outlines methods for pathogen detection which typically contain three steps: 1) preparation of the food matrix, 2) separation/isolation of the target bacteria from the food matrix and 3) the identification of the bacteria (2). Despite the advances in the development of the rapid detection of foodborne bacteria, there remain significant challenges for the improvement of the separation step. Without the ability to physically separate and concentrate the bacteria from the food matrix, many of these new detection techniques cannot be put into practice $(6,39,49)$. Additionally, possible inhibitors, particulates, and competing chemistries can make conducting rapid and sensitive pathogen detection in food matrix difficult. Currently the food and agricultural industries rely mostly on standard microbiological methods to detect the presence of bacteria (53). However, the complexity of foods makes the sample preparation difficult and raises the possibility of false negative results $(39,49)$. Another obstacle to pathogen separation is that bacterial cells can form relatively strong attachments to the surface and interior of the food which also makes separation from the matrix much more complex (16). Therefore, while new technologies have shown the advantages in the rapid detection of pathogen in food matrices, the bacterial separation process remains the bottleneck $(6,49)$. In order to truly reduce the time from

sample preparation to results, it is necessary to investigate new possibilities for bacteria separation.

Produce has been recognized as a leading contributor of foodborne illness. Specifically, leafy greens are the number one vegetable to be associated with outbreaks and illness as they are 
often consumed raw with minimal cleaning $(17,22)$. However, there is continued increase in market demand for fresh produce, such as lettuce and spinach yet these ready-to-eat foods are often prepared in salads and therefore consumed without a thorough kill step.

Salmonella is a pathogen which continues to be of critical concern for food producers and consumers and this organism is commonly associated with contaminated fresh vegetables $(9,28$, 41). Additionally, many bacteria such as Salmonella, can become internalized within the plant tissue which not only makes them less susceptible to chemical and physical removal methods, but also more difficult to detect $(16,49)$. Factors such as bacteria type and plant surface roughness will have an influence over the physical adhesion between the bacteria and food matrix $(40,56)$. An efficient method to separate Salmonella from the leafy green vegetables would have a profound effect in designing an accurate detection method that would greatly benefit a variety of foods including leafy greens.

There have been many methods developed for the separation of bacteria from a sample matrix. Filtration and centrifugation are two common separation approaches to remove bacteria from liquid samples (49). Immunomagnetic separation (IMS) is another prevalent method for a relatively rapid, clean and specific separation of bacteria from liquid food samples, such as milk and juice. The IMS technique uses magnetic beads $(1-5 \mu \mathrm{m})$ conjugated with specific antibodies which adhere to the bacterial cells and thus help to separate the bacteria in the presence of a strong magnetic field $(12,60)$. Following aspiration of the supernatant, the bead-analyte conjugates are re-suspended in a buffer and used for detection. IMS is a useful tool which can easily separate bacteria from liquid matrix; however for separation in solid matrix additional sample preparation might be required.

Current traditional methods for homogenizing a sample and separating bacteria from solid food matrices include stomaching, blending and manually shaking $(6,33,34)$. The current FDA Bacteriological Analytical Manual (BAM) instructions for the isolation of Salmonella from 
leafy green vegetables is manually mixing by vigorously swirling the sample (2). However, there are some concerns that these methods may not be sufficient to detach all the bacteria from the produce. Inoculation studies have demonstrated that the recovery of bacteria using blending were lower than the original inoculation levels thus indicating that blending was not an efficient method $(30,33)$.

Research has speculated that the low bacteria recovery from food matrixes may be attributed to the strong binding affinity between the bacterial cells and the produce and the internalization of bacteria into plant tissue $(16,18,25)$. Therefore, there is increased need to develop an effective separation strategy so that the levels of bacterial contamination are not underestimated. Previous research with raw beef demonstrated that bound bacteria could be released using enzymes such as collagenase and trypsin to degrade the connective tissue prior to separation by centrifugation (42). A similar strategy may be effective for the sample preparation of lettuce and spinach. For leafy green vegetables, the structural components of the plant cells can be broken down in order to release the attached bacteria. These structural components include cellulose and pectin which function to hold the cells together.

This research utilizes a two-step process that aims to improve microbial recovery in leafy green models. This strategy for bacteria separation from lettuce and spinach included enzymatic digestion of the leaves followed by the immunomagnetic separation of bacteria from the liquefied sample (Figure 1.1). Here, we optimized and characterized the enzymatic digestion of Salmonella-inoculated spinach and lettuce. Then immunomagenetic separation was used to capture the Salmonella cells from the liquefied sample. The effect of the enzymatic digestion (cellulase and pectinase) on both the plant material and the efficiency of separation were investigated. 

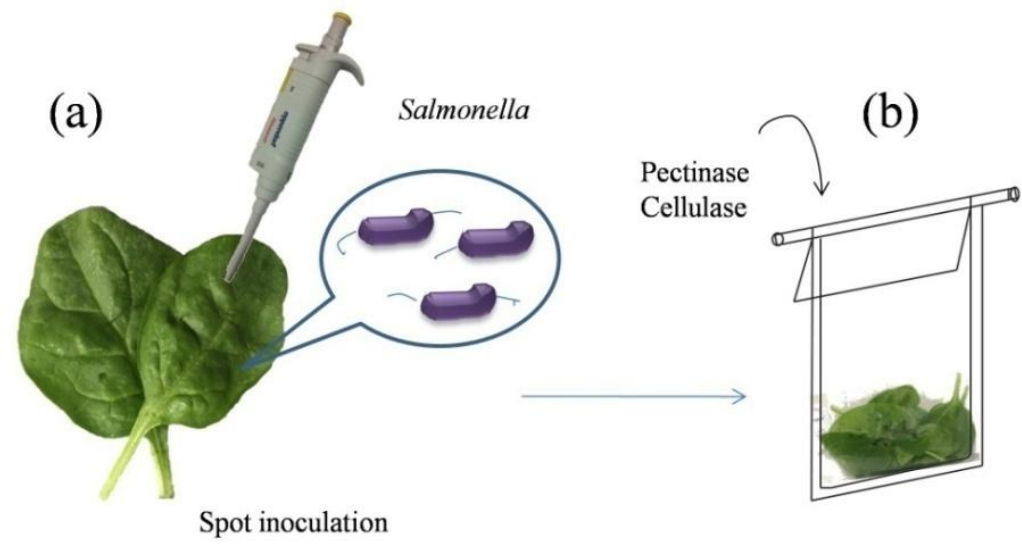

Homogenization for $10 \mathrm{~s}$

Enzymatic digestion at $37^{\circ} \mathrm{C}$ for 1.5 hours

(c)

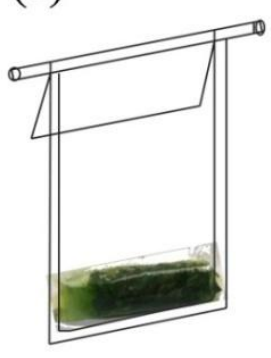

Enzyme digested
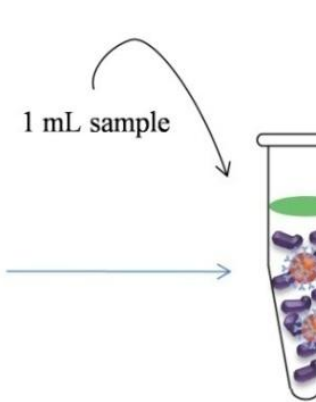

Immunomagnetic separation

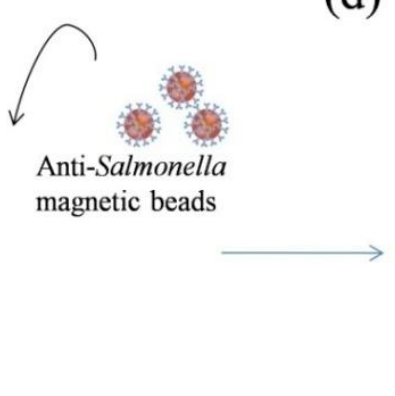

(d)

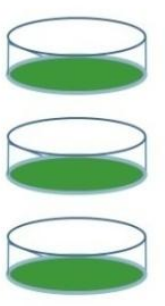

Plate counting

Figure 1.1 Schematic representation of the separation of Salmonella from the spinach using enzymatic digestion with pectinase and cellulase followed by immunomagnetic separation and plate counting. (a) Spot inoculation of Salmonella on the surface of spinach. (b) Enzymatic digestion of spinach at $37{ }^{\circ} \mathrm{C}$ for 1.5 hours. (c) Immunomagnetic separation of the liquefied sample after enzymatic digestion. (d) Plating on HE agar followed by enumeration. 


\section{CHAPTER 2}

\section{BACTERIA CONCENTRATION AND SEPARATION AND THE OBSTACLES OF CURRENT METHODS (LITERATURE REVIEW)}

\subsection{Introduction}

Food safety is an essential part for the food industry and has been attracting a lot of attention from the government, research and regulatory agencies. For decades they were recognized as important issues in many countries. Foodborne pathogen is the main risk that threats the system of food safety and causes some serious foodborne illness. The food industry shows the most concern about the presence of the pathogenic bacteria and a failing of detection of the pathogen may lead to an outbreak which affects the health of the general public $(46,53)$. Although the food safety has been improved gradually, the foodborne outbreaks from the contaminated food are still common in many countries and trading of the contaminated food among countries increases the potential risk of outbreaks. The health risks caused by foodborne pathogen present the major concern to all governments. Therefore, the general public provides an intense need for the study of food pathogen detection (53).

The process of the analysis of microorganisms typically includes the sampling, separation and concentration of target bacteria followed by the detection (Figure 2.1). New technologies show promise as sensitive detection methods, but require a relatively clean sample in a small volume. Bacterial concentration and separation has an essential role in the development of the sensitive and accurate detection methods for foodborne pathogens, however an efficient bacterial separation remains the bottleneck for rapid pathogen detection in food and agriculture. Without an effective separation method, it is difficult to satisfy the need for the rapid and sensitive screening of pathogens on agricultural samples. Bacterial concentration and separation is aimed to concentrate and isolate the target bacteria from the complex matrix with removal of the interference that affects the detection results. 


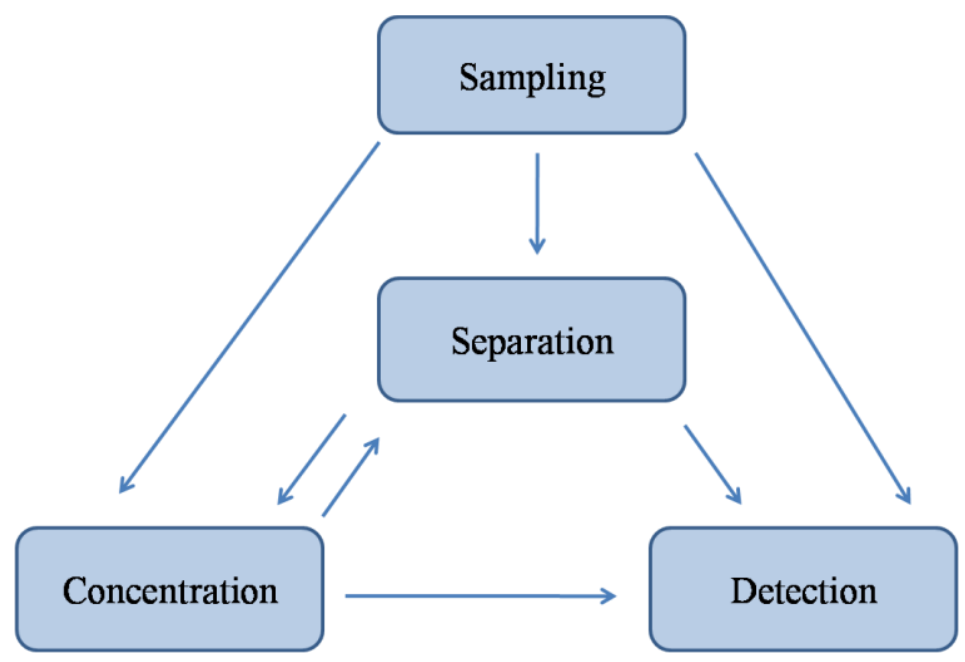

Figure 2.1 Schematic of food microbiological analysis (Source: Brehm-Stecher et al, 2009) (6)

\subsection{Current situation of food safety}

\subsubsection{Food safety regulations}

In order to ensure the food safety, there are some food agencies and legislature which regulate the food industry. With the rapid development of the global economy, there is more trade corporation among different countries which increases the potential of outbreaks when the contaminated food was traded $(20,53)$. The strict regulations on the safety of the food product demonstrated not only the significance of the food safety issues, but also the great demand for the rapid and accurate detection methods of pathogen. If the foodborne pathogen can be detected accurately and rapidly, many outbreaks can be avoided in advance. The conventional methods are the most commonly used and accurate to detect pathogenic bacteria with the limitation of time consuming. Recently there is an increasing interest in the development of rapid detection methods for the foodborne pathogens.

\subsubsection{Foodborne pathogen and foodborne diseases}

Foodborne illness has attracted more attention from the general public, continuing to be a major public health problem and a widespread health issue $(46,53)$. Foodborne illness is defined as diseases by the World Health Organization (WHO) and usually either infectious or toxic in 
nature which is caused by foodborne pathogen when consume the contaminated food. It is difficult to have an accurate estimate of the incidence of the foodborne disease. Foodborne illness sometimes is complicated because very few illnesses can be definitively associated with food products and only during the outbreak situations that the illness can be linked to foodborne pathogens (20). The Centers for Disease Control and Prevention (CDC) estimated that 19,162 laboratory-confirmed cases of infection, resulting in 4,276 hospitalizations and 88 deaths in 2013 in the USA according to the FoodNet 2013 Annual Report (10). In the study of outbreaks reported to CDC by Center for Science in the Public Interest (CSPI), there was a total of 9, 625 outbreaks which were responsible for 193,754 illnesses between 2004 and 2013, in which only 3,485 outbreaks were fully solved with both an identified food and contaminant. The fresh produce remains the leading food associated with outbreaks, with 643 (19\% of total outbreaks), and 20,456 illnesses (24\% of total illness) (9). .Because the fresh produce such as cucumbers, cantaloupes and peppers are often consumed raw with minimum heat processing, resulting more foodborne illness. Foodborne disease not only has a significant influence on people's health but also has the economic consequence for families and individuals, even the countries. The outbreaks associated with foodborne pathogens reduce economic productivity and impose a burden on the health-care systems. Therefore, the food safety is vital for both the health of people and economic development of the country.

One of the most essential parts to control the food safety is the development of effective bacterial separation methods and pathogen detection methods. This is the key for food industry to identify and subsequently prevent the problems related to food safety and human health. A variety of foodborne pathogens have been found to be associated with the foodborne illness, however the top five pathogens contributing to the majority of foodborne outbreaks are Salmonella, Escherichia coli O157:H7, Campylobacter and Listeria monocytogenes (1, 11). Escherichia coli are a group of enteric pathogens, of which E. coli $\mathrm{O} 157: \mathrm{H} 7$ is the most well- 
known bacteria for causing the serious foodborne illness. Escherichia coli is also a model bacteria that have been the most thoroughly and commonly studied for the research on the bacterial detection. Salmonella has the largest research papers reported about its rapid detection and WHO reported that salmonellosis caused by Salmonella spp. is the most frequently reported foodborne illness worldwide (43). Salmonella is a gram-negative facultative bacteria with a worldwide importance which causes as many as 1.3 billion cases of disease each year (14).

\subsection{Bacterial concentration and separation}

Bacterial concentration and separation is a critical part in the sample preparation. Bacterial concentration can be defined as the reduction of the sample size with a recovery of all the initial bacteria of interest. Bacterial separation is the removal of the target bacteria from a complex matrix. Therefore, the aim of this step during the bacterial detection is to pre-concentrate and isolate the target bacteria with removal of the matrix interferences that may affect the detection, such as fats, proteins and enzyme, providing a low-volume liquid sample $(6,49)$. The major challenges include the impact of components in the complex food matrix and the potential interference with the detection system. Bacterial separation and concentration is often the bottleneck of an effective detection because it depends on the food matrix and analytes (23). There are a variety of methods that have been used to accomplish the bacterial separation and concentration. The target microorganisms must maintain its viability during all steps otherwise the concentration of the analyte will be underestimated. When multiple steps are conducted to separate and concentrate bacteria, there should be a balance between the recovery and the purity. The minimal steps are trying to be used with allowing the detection of the select bacteria in the matrix at the required concentration of interest. Currently the development of new techniques for the bacterial separation is attempted to enhance selectivity and employ small amounts of sample prior to analysis, minimizing the number of steps and reducing solvent consumption. An effective 
bacterial separation and concentration should facilitate the achievement of a rapid and sensitive detection of pathogen.

\subsubsection{Bacterial separation from the solid food matrix}

\subsubsection{Principle of bacterial attachment on the solid food sample}

The adsorption of bacteria to solid food sample or its surfaces is mediated by nonspecific and reversible physicochemical interactions and the contents of the bacterial cell wall. Most of the microorganisms have a negative charge while the food components usually have the positive charge, thus bacteria have the potential to be adsorbed to the food matrix. During the process of bacterial separation, the interaction between the bacterial cells and food matrix needs to be destroyed without influence on the viability of the bacterial cell and the reoccurring of adsorption should be prevented (49). The attachment of bacteria to the surface of the food matrix or the internalization of bacteria in the tissue of plants would result in a false negative result due to incomplete recovery of target pathogen (16). Therefore, the first goal of the bacterial separation from the solid food matrix is to release the bacteria into an aqueous sample, then following the strategies of separating target bacteria from the aqueous sample. It describes briefly the methods that currently exist to separate bacteria from solid food matrix below.

\subsubsection{Ultrasound}

Ultrasound wave (sonication) is a physical separation method which applies the sound energy to agitate the liquid sample. The sound energy help to detach the target bacteria from the surfaces of the solid food sample (37). It is usually combined with other methods such as filtration to achieve a higher recovery. Ultrasound is a simple method which involves less equipment and less time, however there are many factors that limit the use of ultrasound technology for bacterial separation. For example, it needs high concentrations of cell to conduct the ultrasound. In addition, the data on recovery efficiency of bacteria after ultrasound were limited which means the effect of ultrasound on the viability of bacteria was unknown. 


\subsubsection{Stomaching}

Stomaching is a physical procedure to separate bacteria which is attached to the surface of solid food matrix by using the mechanical force to disrupt the interaction between the bacteria and food component. The adequate physical forces are applied to the sample through the flexible walls of bags (47). The sample is put into the buffer inside the stomaching bag and sealed followed by applying forces to the outside of the bag by means of wheels, rollers or paddles. The two paddles, side by side, alternately press the bag and compress the sample in the bag against the door. Bacterial separation is achieved by violent shearing forces as the liquid is swept from side to side, and partly by the series of rapid compressions the sample as it is trapped under the paddles (61). It is also a way to mix the solid sample and make them homogenous in the liquid solution. Stomaching is commonly used to homogenize the sample and remove the bacteria from the solid matrix.

Stomaching offers many advantages as a separation method for food matrix (47). For the shaking or gently mixing, the bacterial suspensions from food might not immediately be dispersed in water. Stomaching can overcome this obstacle. It can also save the labor to clean the homogenizer cup or blender cup. The plastic bags used in the stomaching can be disposable, require little storage space and can be easily transported. In addition, stomaching method yields less debris than blending (61). The limitation of this method is the low recovery of the bacteria from the food contains high fat content. The bacteria recovery from a high fat food matrix using stomaching was lower than that using conventional blending.

\subsubsection{Blending}

Blending is another physical method which involves mechanical force to separate and homogenize the sample. The blade which contributes the mechanical force is usually in the bottom of a blender and the rotary speed of the blade can be controlled. The blade can cut the food matrix into small pieces and the centrifugal force formed during the blending promotes the 
separation of bacteria from the surface of the food matrix. Blending can provide high mechanical energy to mix the food sample, however the physical force has the potential to affect the viability of the bacteria. Compared with stomaching, the sample adhered to the wall of blender cup and blade is not easy to clean which increases the labor cost and time and poses the risk of crosscontamination between the samples.

\subsubsection{Bacterial separation from the liquid food matrix}

\subsubsection{Centrifugation}

Centrifugation is a physical separation method which involves the use of the centrifugal force to propel the particulates suspended in a liquid sample to sediment. It is a simple and rapid method in separation and concentration of bacteria and achieved success in many applications. It can be used to separate two immiscible liquids. In the application of bacterial separation, the effective centrifugal force causes the bacteria (pellet) to accumulate on the bottom of the tube and the supernatant liquid is then discarded without disturbing the pellet. The rate of the sedimentation depends on several of physical factors which can be described by Stokes equation. Generally centrifugation is specified by the relative centrifugal force applied. After the centrifugation, the supernatant is discarded and the bacteria is resuspended in the buffer or broth for further assay or it can be resuspended in buffer with a small volume to achieve the aim of concentration (32). The limitation of the bacterial separation by centrifugation from food containing fat, such as meat or dairy products, is not easy to be achieved. The reason is that the fat globules may trap the bacteria which prevent the sedimentation. In addition, highly viscous foods also have this similar potential problem. Other methods should be considered to combine with centrifugation to develop the effective bacterial separation method.

\subsubsection{Filtration}

Filtration is also a common physical method that can be used to concentrate and separate bacteria from the aqueous food matrix. It is usually applied in the separation of solids from the 
liquids by using a filter to retain the select solids. The aqueous food matrix passes through a filter and target bacteria are retained on the filter while the liquid food sample is discarded. The solid that retented on the filter depends upon the size of the microorganisms and pore of the filter (21). Then the bacteria can be removed from the filter by elution if needed. We can control the size of the pore of the filter to retain the bacteria which are interested in. The bacteria are separated and concentrate on the filter for further assay after the filtration. However, the limitation of the filtration is that it is not able to distinguish the bacteria or other inhibitory components with the similar size. High levels of particulates in the food matrix will clog the filter. It is also limited to the volume of sample that can be passed through the filter. The filterability of the sample is able to be improved by the pre-enrichment with enzymes and detergents but the cell viability may be affected. In addition, bacteria may be trapped within the pores of filter which increases the difficulties in the removal of bacteria from the filter after filtration. The recovery of the bacteria from the filter is also an issue and challenge. The bacteria recovered from filtration are almost always lower than the initial bacteria and the filter may also reduce the ability of bacteria to grow on the solid media.

\subsubsection{Immunomagnetic separation}

Immunomagnetic separation (IMS) is a biological method for the bacterial separation with high specificity. The magnetic particles coated with specific antibodies on the surface allow a specific capture and isolation of target bacteria from a complex sample suspension. A strong magnet is then employed to capture and extract the target bacteria to the side wall of the tube and then the bacteria captured by the beads are used for further assay (3). The selectivity is dependent on the specificity of monoclonal antibodies against a specific surface protein (epitope) of the bacterial cell and the efficacy relies upon the specific monoclonal antibody, the surface area and size of the particle coated on the antibody, the recovery procedure and sample matrix interference. Small particle is suitable for sensitive detection of small analytes. For the whole 
bacteria, the size of the particle needs to be evaluated to balance the assay time and sensitivity. Immunomagnetic separation has been proved to be an efficient strategy for the concentration and separation of target bacteria from the mixed cell populations including Salmonella spp., E.coli O157:H7, Listeria monocytogenes and enteric viruses. (52). IMS has been included as a standard method to detect E. coli $\mathrm{O} 157: \mathrm{H} 7$ and Salmonella spp. by FDA. IMS can be combined with a variety of detection approaches, such as optical, electrochemical and conventional plating methods.

There are several advantages associated with IMS over than sample preparation, such as high specificity, simple procedure and reduction of sample volume (48). However, despite its promise, the method still has some limitations. The captured bacteria by the magnetic beads may be lost during the washing procedure, and the components in the food matrix, such as fat or protein may interfere the binding of antibody and antigen resulting a non-specific binding or bacteria adherence.

\subsubsection{Bacteriophage}

Bacteriophage has the potential to selectively separate and concentrate the specific bacteria cells. Bacteriophages are viruses that bind to specific sites on the surface of the bacteria followed by injecting their gene inside the specific bacteria. Phages are extremely host-specific and infect specific to live bacteria. So the use of the phage can help distinguish and separate the dead and living cells (26). There have been several researches involved in using phage to separate the bacteria followed by other detection methods $(13,57)$. The detection methods for Salmonella and E.coli $\mathrm{O} 157: \mathrm{H} 7$ based on bacteriophage form foods matrix are commercially available.

Phage-based separation has the advantage of greater adaptability due to its broader environmental and storage stabilities. Phages infect bacteria and amplify, resulting in the host being lysed and large number of phage being release (13). However, the target bacteria after the phage-based separation are not compatible with identification systems based on culture because 
the bacteria cells have been lysed during the separation. It needs more research on the development of the technologies that can be compatible with phage system and optimization of phage-binding efficiency and immobilization. In this way, this method can be further applied in food systems and other fields.

\subsection{The obstacles of the current separation methods}

The current methods used for bacterial separation may not be efficient for the entire food matrix because of the strong attachment and internalization of bacteria. It may be possible to achieve a false negative result due to poor sample preparation or technique. There are also some concerns about the effectiveness when using the simple physical methods to remove the bacteria. Some bacteria are able to strongly attach to the surface of food matrix or internalize within the food matrix $(18,19)$. If the microorganism present in very high number, there is also potential to form biofilm on the surface which increases the difficulty of bacterial separation. The blending is a useful approach to homogenize the plant material and separate the surface bacteria; however it may degrade DNA and release PCR inhibitors. Given the diversity of food products, the complexity of foods will require several separation strategies based on the characteristics of food matrix. There is different requirement of separation for each bacteria or food matrix (33).

There are many possible reasons for the fresh produce associated with increasing numbers of outbreaks. There is a greater demand for the fresh vegetables and fruits and more usage makes outbreaks more prominent. The global trading increased the risk of cross contamination. In addition, the process of cutting and packaging is another source of contamination because there is no pathogen killing step during this procedure. The consumption of fresh vegetables with minimal processing has increased. Bacteria can attach to the surface or enter into the tissue of the plant.

The pathogenic bacteria, such as E. coli O157:H7 and Salmonella can be attached and possible internalized within the fresh produce during many different points of growing and 
processing. Bacterial internalization can refer to the process that bacteria pass the surface of the food matrix and enter into the inside part of the sample (19). One of the easiest and simplest methods to detect the internalized bacteria is removal of the surface layer of a plant physically and enumeration of the bacteria within the tissues (31). The commonly used approach to identify internalized bacteria is surface sterilization of food matrix contaminated with bacteria followed by tissue maceration and plating. The limitation of this approach is that the bacteria indentified internalization may not only from the inside of plants but may also from the bacteria survival from the sanitization treatment. Other method using microscopy-based techniques is able to validate both the presence and the location of bacteria within a plant $(29,58)$.

The research on the comparison of different separation methods was conducted by many researchers. The recovery of E. coli $\mathrm{O} 157: \mathrm{H} 7$ and non-O157:H7 STECs from baby spinach were compared between using rinsing and soaking method for separation, respectively. The results of both kinds of $E$. coli were similar, with the soaking method being significantly more effective than rinsing method (33). Another study was conducted on investigate the bacterial recovery after pulsifying, pummeling, sonication and manually shaking. The results showed that the number of bacteria recovered after pulsifying and pummeling were higher than those recovered after sonication and manually shaking for the majority of vegetable leaves. There is still a need for the strategy to isolate internalized bacteria which cannot be easily removed by physical methods.

\subsection{Enzyme technology in bacteria separation}

There are many factors that may affect the potential of the internalization of bacteria within a plant, such as the serovar or strain of bacteria, plant species and source of contamination. Several studies have shown that bacteria may enter into the tissue of plants through the opening sites of a plant, such as stomata, cavity and physical damaged leaves $(5,35)$. There was study showing that the disruption of stomata resulted in a failure of internalization for bacteria within the plan tissue, providing the evidence that stoma have critical role in the internalization of 
bacteria. The destruction or wounding of tissue of plants may provide a favorable environment for the pathogenic bacteria to grow. Some studies have revealed that stomata were one of the main parts for bacteria to assemble using scanning electron microscopy (44). Therefore, bacteria are able to be released from the surface and tissue of the plant with the breaking down of the plant structure. Enzymatic digestion is a commonly used way to disrupt the components that function to put the cells together in plants.

There has been study that using enzymatic digestion prior to other separation methods to detach all the bacteria from food matrix (42). The method using enzyme to digest the tissue of beef prior to centrifugation increased the bacteria released form beef surfaces and increased the numbers detected. Collagenase and trypsin degraded the connective tissue within the raw beef.

If the target bacteria remain attached to very small particles or internalized within the tissue after the initial physical separation, such as stomaching and blending, the subsequent detection of bacteria might not be accurate, resulting in the underestimation of bacterial contamination. The enzyme treatment is a way to release bacteria with the digestion of large particulate and disruption of the structure. This strategy is able to be potentially used for a variety of food matrix with the appropriate enzyme combinations.

\subsection{Conclusions}

Food safety continues to be an important issue for the human health and food industry. There has been tremendous improvement in technologies about the rapid detection of food pathogens. However, the bacterial separation and concentration which is a critical part for the detection remains the bottleneck. The ability to perform an efficient and rapid separation and concentration would enable several advanced detection technologies. An ideal downstream detection system would allow multiplex identification of several pathogens. There have been many strategies developed for concentration and separation of bacteria from food matrix. The separation method used for each food matrix might be different based on the complexity and 
characteristics of food sample. Bacterial cells can form relatively strong attachments to food and plant, making separation of bacteria problematic. The current methods used for separation of bacteria from solid food matrix usually involve the physical methods, such as blending, stomaching and shaking. The main obstacle of these methods is the ability of isolate the internalized bacteria. There is still need for an efficient method especially for the bacteria trapped in the tissue of the fresh produce. 


\section{CHAPTER 3}

\section{OPTIMIZATION OF THE CONDITIONS FOR ENZYMATIC DIGESTION}

\subsection{Introduction}

Plant cell walls primarily contribute to the formation and properties of the structure of plants. Plant cell walls, consisting of protein, carbohydrate and aromatic compounds, are critical to the proper growth of plants (8). The main roles of cell walls are to physically support the structure of the plant and to provide a barrier against the outside environment (45). The cell wall of the plants is a thin, strong and flexible extracellular layer which is made of complex polysaccharides and a small amount of structural proteins (15). Matrix polysaccharides include cellulose and acid polysaccharides (pectins). The polysaccharides components include cellulose and pectin make up about $90 \%$ of the primary wall, and are essential to the structure and function of the plants. A variety of polysaccharides help to make up the cell walls (8). Cellulose is the main constituent of plants which is found in the cell walls of plants. The primary cell walls that surround plant cells are fibrous composites in which cellulose microfibrils are combined together by cross-linking glycans. It provides the rigidity needed for the structure and the necessary strength to resist the pressure in plant cells. Cellulose is especially high in leafy green vegetables. It also provides the necessary Pectin is another major component of primary cell walls of all plants and it accounts for about one third of all primary cell wall marcomolecules (38). Pectins link with each other to form a pectic network throughout the cell walls. It has fundamental roles in the structure and function of both primary and secondary wall (59). Therefore, the main components that maintain the structure of the leafy green vegetables such as spinach and lettuce are cellulose and pectin.

In our research, the spinach and lettuce were digested by the enzyme in order to break down the structure of the leaves. Cellulase and pectinase were selected to digest the cellulose and pectin which the main structural components of leafy green vegetables. Cellulase is the group of 
enzymes that hydrolyze cellulose which is polysaccharide that constitutes the plants. Pectinase is the enzyme that is able to break down or to transform pectin which is substrate that stabilizes the cell walls of plants. There are many factors that can affect the result of enzymatic digestion, so the condition of enzymatic digestion needs to be optimized.

\subsection{Materials and Methods}

\subsubsection{Optimization of the enzyme conditions}

Identical brands of fresh bagged spinach and romaine lettuce were purchased from the local market and were stored at $4{ }^{\circ} \mathrm{C}$ and analyzed on the day of purchase. The samples were verified to have no detectible Salmonella prior to inoculation. Leaves with decay, cuts or bruises were identified and discarded. Pectinase (3,000 APSU-CA/g) and cellulase (1,000 BHU-2/g) samples were obtained from Novozyme (Kalundborg, Danmark). Three portions of ten gram samples (spinach or lettuce) were added into individual sterile plastic filter blender bags (Interscience, MA, USA) containing $90 \mathrm{~mL}$ of double strength (2x) modified PBS buffer with $\mathrm{pH}$ 7.0 and $\mathrm{pH} 7.5$, respectively, for the optimal $\mathrm{pH}$ range of pectinase and cellulase. The spinach or lettuce samples were then treated with various volumes $(0.25 \mathrm{~mL}$ to $1.0 \mathrm{~mL})$ of pectinase and cellulase independently or combinations of these two enzymes to achieve different final concentrations of enzymes in the buffer according to the initial concentration of these two enzymes. Due to the different structural components of the plant cell walls, the concentrations of the pectinase and cellulase used for spinach and lettuce were expected to be different. For lettuce, the concentration of pectinase or cellulase was from $0 \mathrm{U} / \mathrm{g}$ to $20 \mathrm{U} / \mathrm{g}$. For spinach, the concentration of pectinase or cellulase was ranging from $0 \mathrm{U} / \mathrm{g}$ to $30 \mathrm{U} / \mathrm{g}$. When the combinations of the enzymes were used, the concentration of pectinase was fixed and the concentration of cellulase was varied. All the samples in the filter bags were mixed in a paddle mixer (BagMixer 400CC; Interscience, MA, USA) at speed 2 (2 strokes per second) for 10 seconds prior to the incubation at $37^{\circ} \mathrm{C}$. In order to evaluate the effect of time to shorten the total assay time, the 
enzymatic digestion was conducted and evaluated at different incubation times $(0,0.5,1.0,1.5$ and 2.0 hours) at $37^{\circ} \mathrm{C}$.

In order to determine the extent of digestion following incubation, the samples were first filtered through filter paper (Whatman 40, pore size: $8 \mu \mathrm{m}$; Sigma-Aldrich, MO, USA) using vacuum filtration. The retentate, which contained the larger leaf particulates, remained on the filter paper was dried in an oven at $100{ }^{\circ} \mathrm{C}$ until the stabilized mass could be recorded as $\mathrm{M}_{2}( \pm$ $0.001 \mathrm{~g})$. The filter paper was also dried in the oven at $100^{\circ} \mathrm{C}$ until its weight did not change prior to using and the mass was recorded as $\mathrm{M}_{1}( \pm 0.001 \mathrm{~g})$. Original leaf mass was determined by taking 10 grams of fresh spinach and lettuce leaves respectively and weighing the retentate after drying treatment as $\mathrm{M}_{\mathrm{o}}( \pm 0.001 \mathrm{~g})$. The weight of the original leaves after drying was reported as $\mathrm{M}_{0^{-}} \mathrm{M}_{1}$. The retentate of the leaves was calculated as the change of mass $\left(\Delta \mathrm{M}=\mathrm{M}_{2}-\mathrm{M}_{1}\right)$ and the percentage of the leaves digested was calculated as digestion percentage $=\left[1-\Delta M /\left(M_{0}-M_{1}\right)\right] \times$ $100 \%$. All experiments were conducted in triplicate to confirm reproducibility.

\subsubsection{Scanning electron microscopy}

Lettuce and spinach leaves were treated with 1.5 hours of enzymatic digestion, and then immersed in a liquid nitrogen immersion for rapid freezing. The samples were then lyophilized in a VirTis general purpose freeze dryer (SP Scientific, PA, USA) for 24 hours. After the lyophilization, the leaves were sputter coated with gold (Cressington Scientific Instruments, Watford, UK) for better SEM imaging quality. The Au coated sample was inserted into a JCM6000PLUS NeoScope Benchtop scanning electron microscope (JEOL, MA, USA) operated at a voltage of $10 \mathrm{kV}$. Control samples (incubation without enzymatic digestion) were also evaluated for visual comparison.

\subsubsection{Statistical Analysis}

Data were analyzed by ANOVA using SAS software (SAS Institute, Inc., Cary, NC). Tukey's HSD test was used to determine the significant differences of mean values. A "p value" 
of less than 0.05 was considered statistically significant. The data presented represents a mean of a minimum of three independent samples and error bars represent the standard deviation of the replicates.

\subsection{Results and Discussion}

\subsubsection{Optimization of the $\mathrm{pH}$ and time of the enzymatic digestion}

In order to achieve a more efficient separation, it was necessary to optimize the conditions for enzymatic digestion of spinach and lettuce to maximize the breakdown of the physical structure. The effect of enzyme concentrations was determined to find the optimal concentrations of cellulase and pectinase necessary to digest spinach and lettuce. There are many critical factors which influence the enzyme reaction, such as temperature, $\mathrm{pH}$, and incubation time. The active and optimal $\mathrm{pH}$ and temperature ranges were determined.

For pectinase, the active $\mathrm{pH}$ range is $7.0-8.0$ and active temperature range is $35-65^{\circ} \mathrm{C}$. For cellulase, the $\mathrm{pH}$ active range is 5.0-7.0 and active temperature range is $35-60^{\circ} \mathrm{C}$. Salmonella has an optimal $\mathrm{pH}$ range of 7.0-7.5 and an optimal temperature of $35-37^{\circ} \mathrm{C}$ for growth $(27)$. Therefore, in order to maintain the activity for both of these two enzymes and maintain viability of inoculated Salmonella, a neutral $\mathrm{pH}$ range was selected. The $\mathrm{pH}$ of 2x PBS buffer was adjusted to 7.0 or 7.5 , respectively, and the enzymatic digestion results were compared after using the buffer with different $\mathrm{pH}$. Our results demonstrated that there was no significant difference $(\mathrm{P}>0.05)$ between the groups of $\mathrm{pH} 7.0$ and $\mathrm{pH} 7.5$ (Figure 3.1). The difference of the digestion percentage between $\mathrm{pH} 7.0$ and $\mathrm{pH} 7.5$ was non-significant for both lettuce and spinach. The $\mathrm{pH}$ of the buffer was selected based on other contributing factors, such as the more important role of pectinase and the viability of Salmonella. Finally, the $\mathrm{pH}$ of the buffer was adjusted as 7.4 and the temperature of enzymatic digestion was selected at $37{ }^{\circ} \mathrm{C}$ to allow ideal conditions for Salmonella. Figure 3.2 represents the enzymatic digestion percentage of lettuce and spinach after digesting for different times using either the single enzyme or the combination of pectinase and cellulase. The digestion 
percentage was increased accordingly with incubation time and reached a plateau after approximately 1.5 hours. The result suggested that 1.5 hours was sufficient for the enzyme to complete the digestion of spinach and lettuce. Therefore, 1.5 hours was selected as the digestion time for the investigation of the enzymatic concentration in subsequent studies.

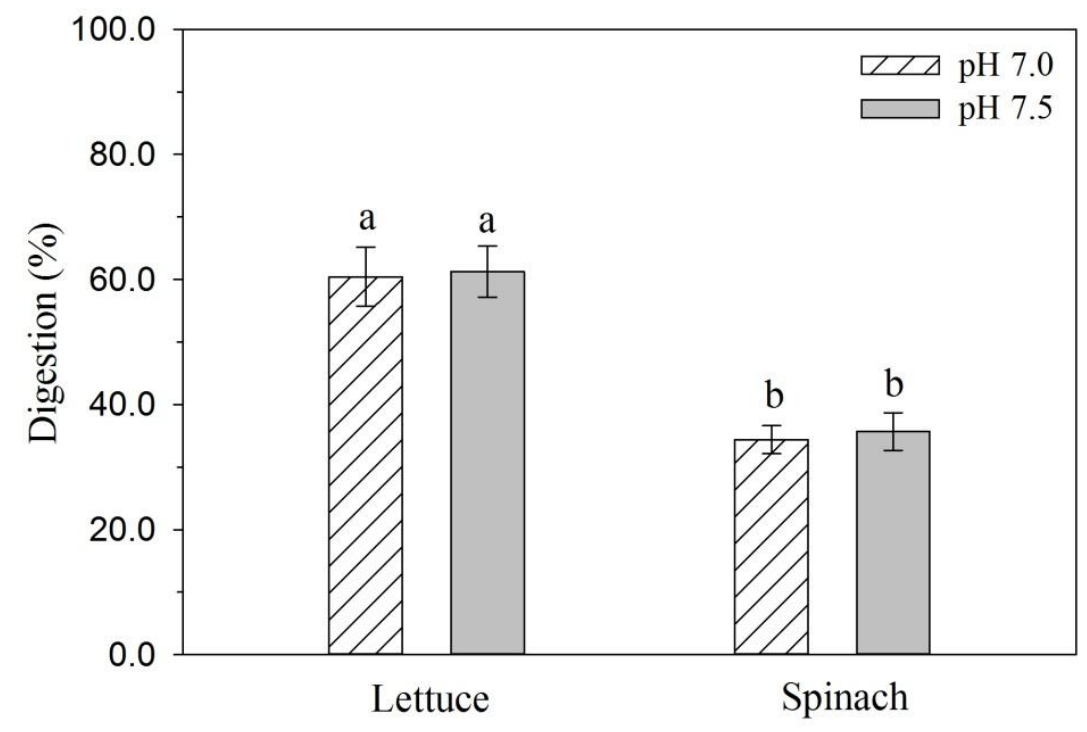

Figure 3.1 The results of enzymatic digestion of lettuce and spinach in $2 \times$ PBS buffer with pH 7.0 and $\mathrm{pH} 7.5$, respectively. The white bars with oblique lines represent the digestion results using PBS buffer with pH 7.0 and the grey bars represent the digestion results using PBS buffer with $\mathrm{pH}$ 7.5. Bars with same letter are not significantly different $(\mathrm{P}>0.05)$ between $\mathrm{pH} 7.0$ and $\mathrm{pH}$ 7.5. The error bars represent the standard deviation of three measurements. 


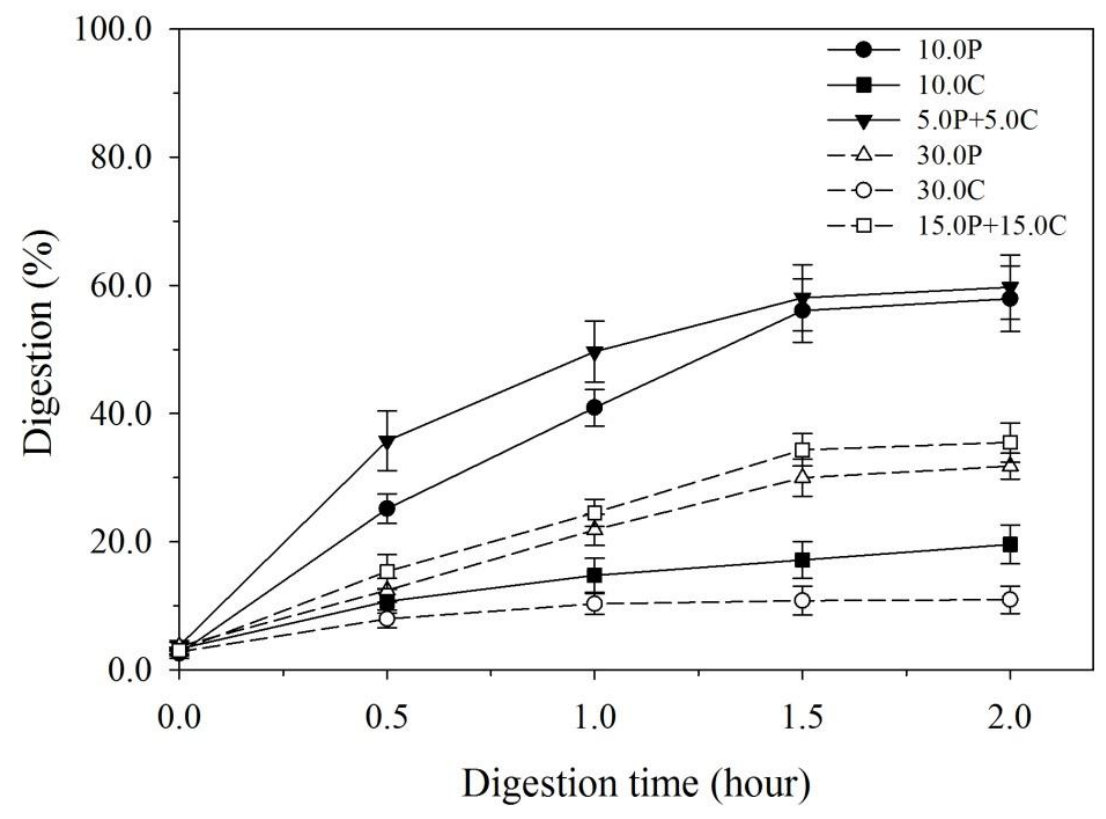

Figure 3.2 The percentage of enzymatic digestion of lettuce (solid line) and spinach (dotted line) after incubation for $0,0.5,1.0,1.5,2.0$ hours at $37^{\circ} \mathrm{C}$. The enzymes used for lettuce were $10.0 \mathrm{U} / \mathrm{g}$ pectinase, $10.0 \mathrm{U} / \mathrm{g}$ cellulase and the combination of $5.0 \mathrm{U} / \mathrm{g}$ pectinase and $5.0 \mathrm{U} / \mathrm{g}$ cellulase, respectively. The enzymes used for spinach were $30.0 \mathrm{U} / \mathrm{g}$ pectinase, $30.0 \mathrm{U} / \mathrm{g}$ cellulase and the combination of $15.0 \mathrm{U} / \mathrm{g}$ pectinase and $15.0 \mathrm{U} / \mathrm{g}$ cellulase, respectively.

\subsubsection{Optimization of the concentration of the enzymatic digestion}

Optimized enzyme ratios and concentrations were reported by increased plant mass (g) after filtration (Figure 3.3). The cellulase alone and pectinase alone was first used to conduct the digestion, respectively and the results were shown in Figure 3.3(a) and (b). Overall, the digestion percentage increased with the independent concentrations of pectinase and cellulase increased for both lettuce and spinach. A higher percentage of enzymatic digestion represented increased breakdown of the plant material. The digestion percentage was increased until the concentration reached $7.5 \mathrm{U} / \mathrm{g}$ for pectinase and $3.0 \mathrm{U} / \mathrm{g}$ for cellulase, respectively. For spinach, 
the digestion percentage increased and leveled off at $22.5 \mathrm{U} / \mathrm{g}$ for pectinase and $7.0 \mathrm{U} / \mathrm{g}$ for cellulase, respectively. For both lettuce and spinach, the retentate percentage of leaves after digestion by only cellulase was twice as much as that by pectinase when the same concentration of pectinase or cellulase was used. The results suggested that pectinase digested leaves more efficiently than cellulose. When comparing the spinach with lettuce, we observed that spinach required more enzymes to achieve a similar amount of digestion as the lettuce.
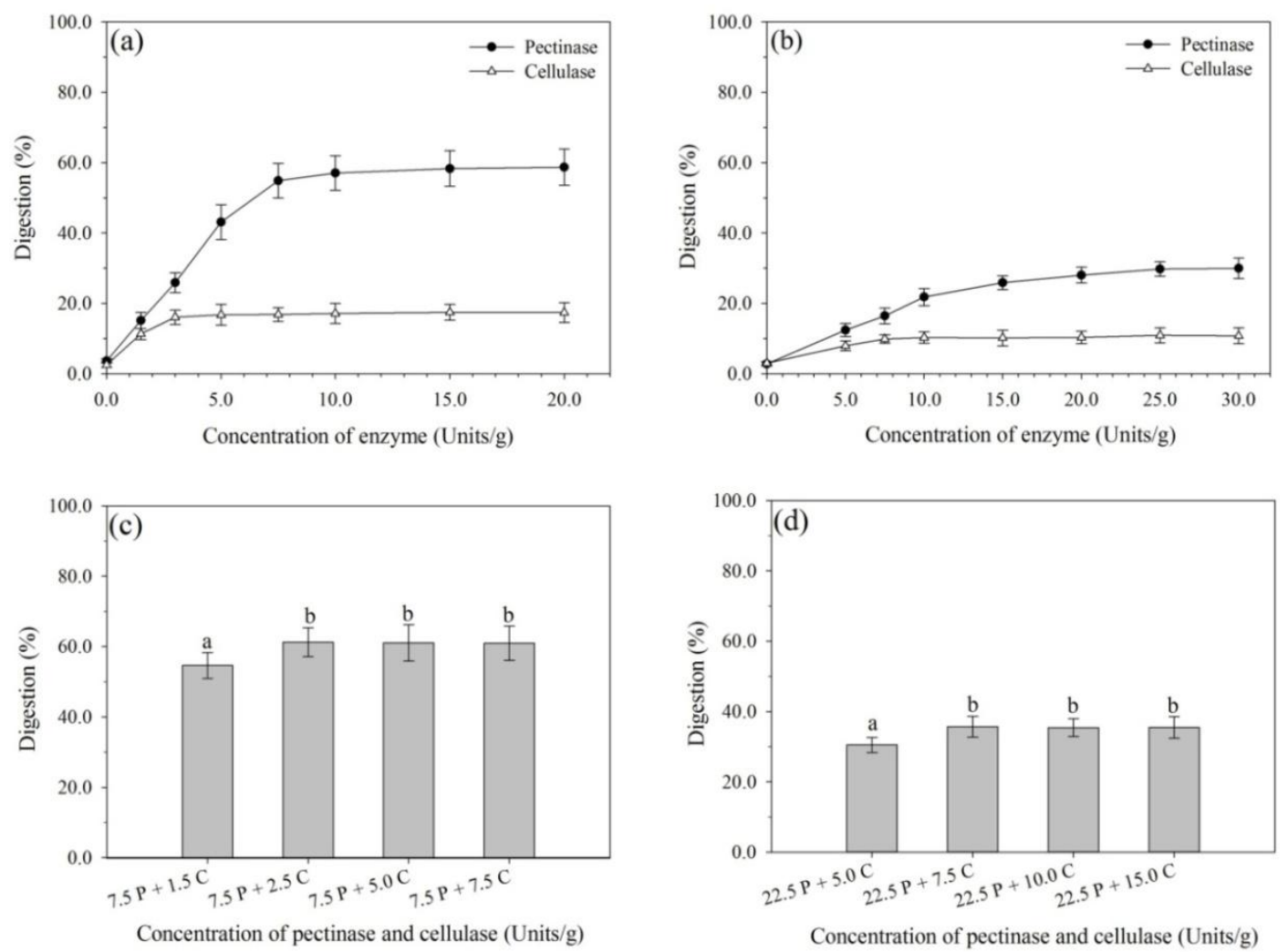

Figure 3.3 The digestion percentage of the leaves of (a) (c) lettuce and (b) (d) spinach, respectively. The results were obtained after digestion using varying concentrations of pectinase (a) or cellulase (b) in the buffer with $\mathrm{pH} 7.0$ and the combination of the enzymes (c) (d) in the buffer with $\mathrm{pH} 7.4$ for 1.5 hours at $37{ }^{\circ} \mathrm{C}$ and after filtration. In each panel bars with same letter (a or b) are not significantly different $(\mathrm{P}>0.05)$ among varying combinations of enzymes. 
The effect of the pectinase and cellulose were first determined individually followed by the combinations of the two enzymes (Figure 3.3(c) (d)). From these data, an optimal combination of the enzymes was determined for both spinach and lettuce. The results suggested that pectinase had a more significant role in the digestion of both spinach and lettuce than cellulase. Therefore, when the combinations of pectinase and cellulase were investigated, the concentration of pectinase was fixed at the optimal concentration and the concentration of cellulase was varied to find the optimal combinations of these two enzymes. For lettuce, $7.5 \mathrm{U} / \mathrm{g}$ of pectinase was combined with various concentrations of cellulase to digest the leaves. We can observe from Figure 3.3(c) that $7.5 \mathrm{U} / \mathrm{g}$ of pectinase and $2.5 \mathrm{U} / \mathrm{g}$ of cellulase was the optimal combination for digestion of lettuce. The addition of cellulase over $2.5 \mathrm{U} / \mathrm{g}$ did not result in improved digestion of lettuce. For spinach, different concentrations of cellulase were investigated with the combination of $22.5 \mathrm{U} / \mathrm{g}$ pectinase. The results suggested that $22.5 \mathrm{U} / \mathrm{g}$ pectinase and 7.5 U/g cellulase was sufficient to digest spinach and the addition of more enzyme had no significant effect on digestion (as shown in Figure 3.3(d)). Overall, $7.5 \mathrm{U} / \mathrm{g}$ pectinase and $2.5 \mathrm{U} / \mathrm{g}$ cellulase were selected and used to digest lettuce and $22.5 \mathrm{U} / \mathrm{g}$ pectinase and $7.5 \mathrm{U} / \mathrm{g}$ cellulase were used to digest spinach in subsequent experiments.

\subsubsection{Physical appearance and SEM evaluation of enzymatic digestion}

After the optimization of the enzyme combination, the physical appearance and SEM images of the leaves of spinach and lettuce were used to evaluate the result of enzymatic digestion. Pectin and cellulose are the two primary structural components of plants and account for approximately $35 \%$ and $30 \%$ of the cell walls, respectively $(15,54)$. In these experiments, cellulase and pectinase were able to break down the structure of the lettuce and spinach. The

digestion resulted in a visual change (Figure 3.4) and with additional microscopy the more discrete changes to the plant surface was evident (Figure 3.5). 
Figure 3.4 shows the physical appearance of the lettuce and spinach in the filter bag before and after enzyme digestion compared with the control (no enzymes), respectively. Prior to the incubation, both spinach and lettuce had undamaged whole leaves in buffer. Following incubation of 1.5 hours, the leaves of both lettuce and spinach containing the optimized enzyme combinations were broken down to small pieces and the samples were almost completely liquefied. The control showed no significant change and maintained the original physical appearance of the leaves. These results demonstrated that the concentration of the enzyme used in this experiment $(7.5 \mathrm{U} / \mathrm{g}$ pectinase and $2.5 \mathrm{U} / \mathrm{g}$ cellulase for lettuce and $22.5 \mathrm{U} / \mathrm{mL}$ pectinase and 7.5 U/mL cellulase for spinach) had a significant effect on degrading the leaves and was therefore effective for the digestion of lettuce and spinach.

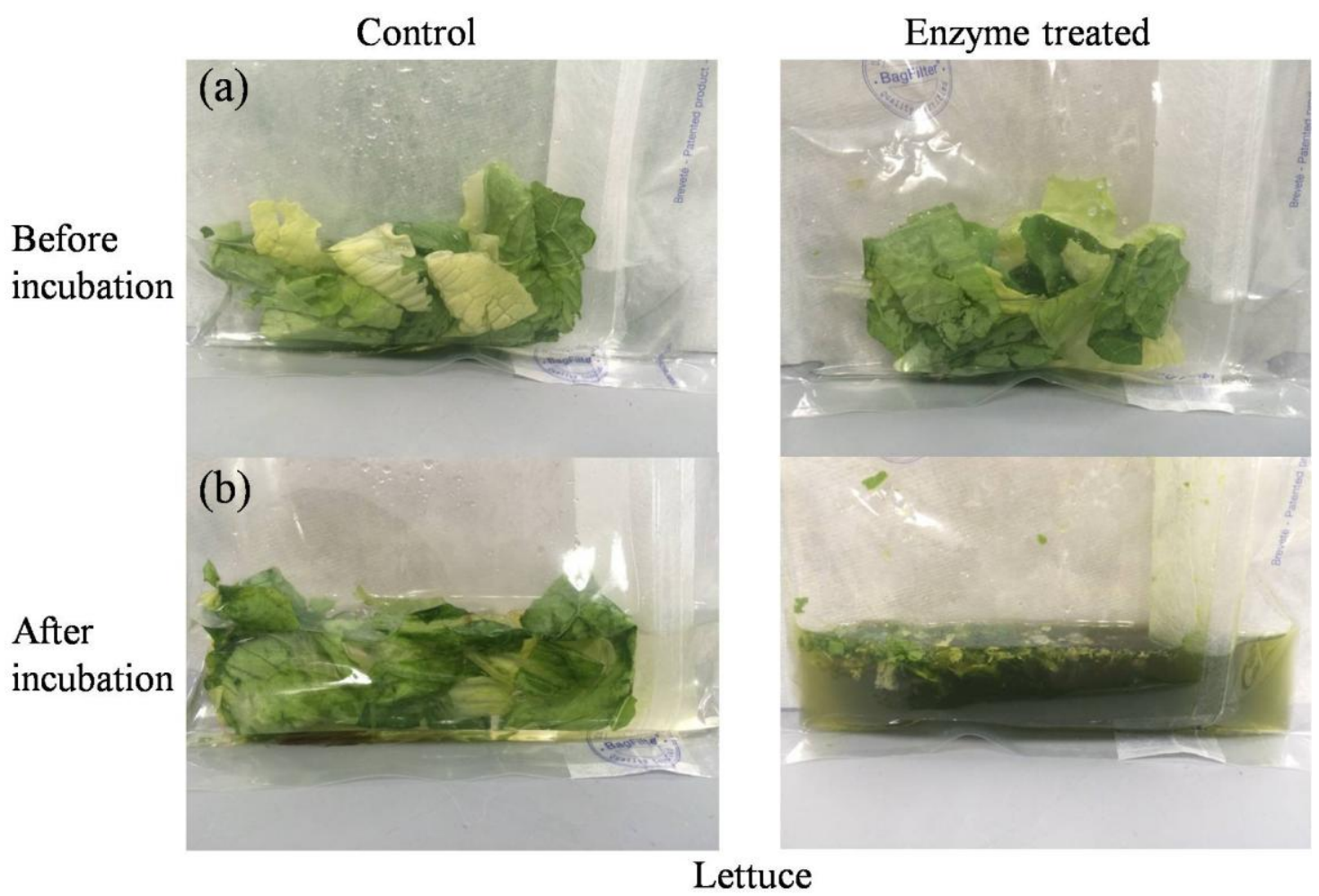




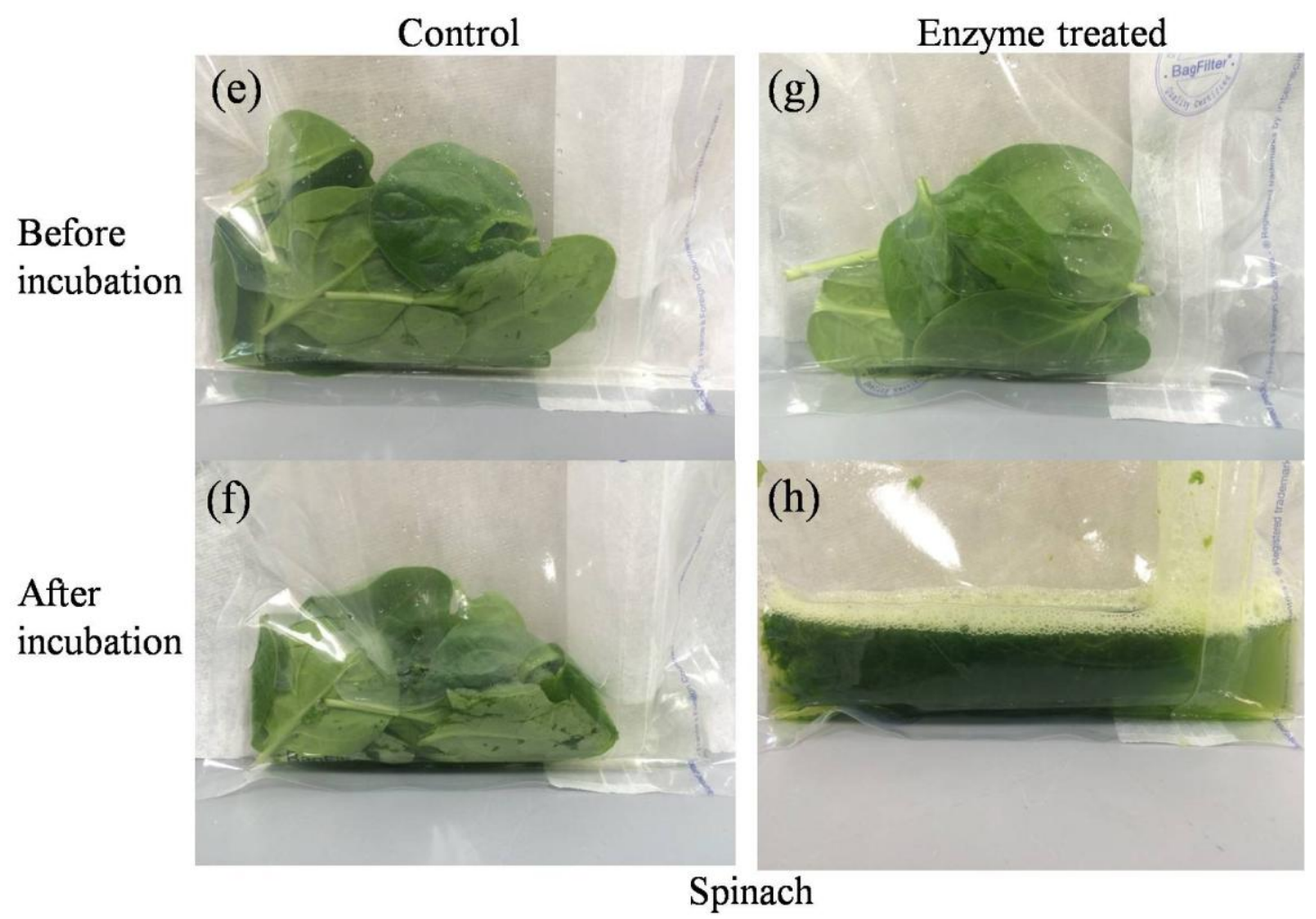

Figure 3.4 The physical appearance of the leaves of lettuce (a) (c) and spinach (e) (g) before the incubation. The physical appearance of the leaves of the lettuce (b) and spinach (f) without enzyme digestion and lettuce (d) and spinach (h) with enzyme digestion after $10 \mathrm{~s}$ of mixing and 1.5 hours of incubation. The concentration of the enzyme used was $7.5 \mathrm{U} / \mathrm{g}$ pectinase and $2.5 \mathrm{U} / \mathrm{g}$ cellulase for lettuce and $22.5 \mathrm{U} / \mathrm{g}$ pectinase and $7.5 \mathrm{U} / \mathrm{g}$ cellulase for spinach.

SEM was used to observe the structural change of the leaves before and after enzymatic digestion. Figure 3.5 (a) (c) shows that before enzymatic digestion, the leaf surfaces of both lettuce and spinach were smooth and intact. We were able to observe the partially closed stomata on the surface of the nondigested leaf. Pathogenic bacteria, such as Salmonella spp. and E. coli O157:H7 have been found to enter into the plant through the natural openings on the produce surface, such as stomata or wounds $(16,35)$. However, after the enzymatic digestion, the leaf degraded and the surface was no longer intact (Figure 3.5 (b) (d)). There were also cracks and 
ruptures on the digested leaf surface. The structure of the leaves was changed and any visible stomata were opened. This suggested that the internalized Salmonella might be released when the structure was broken down.
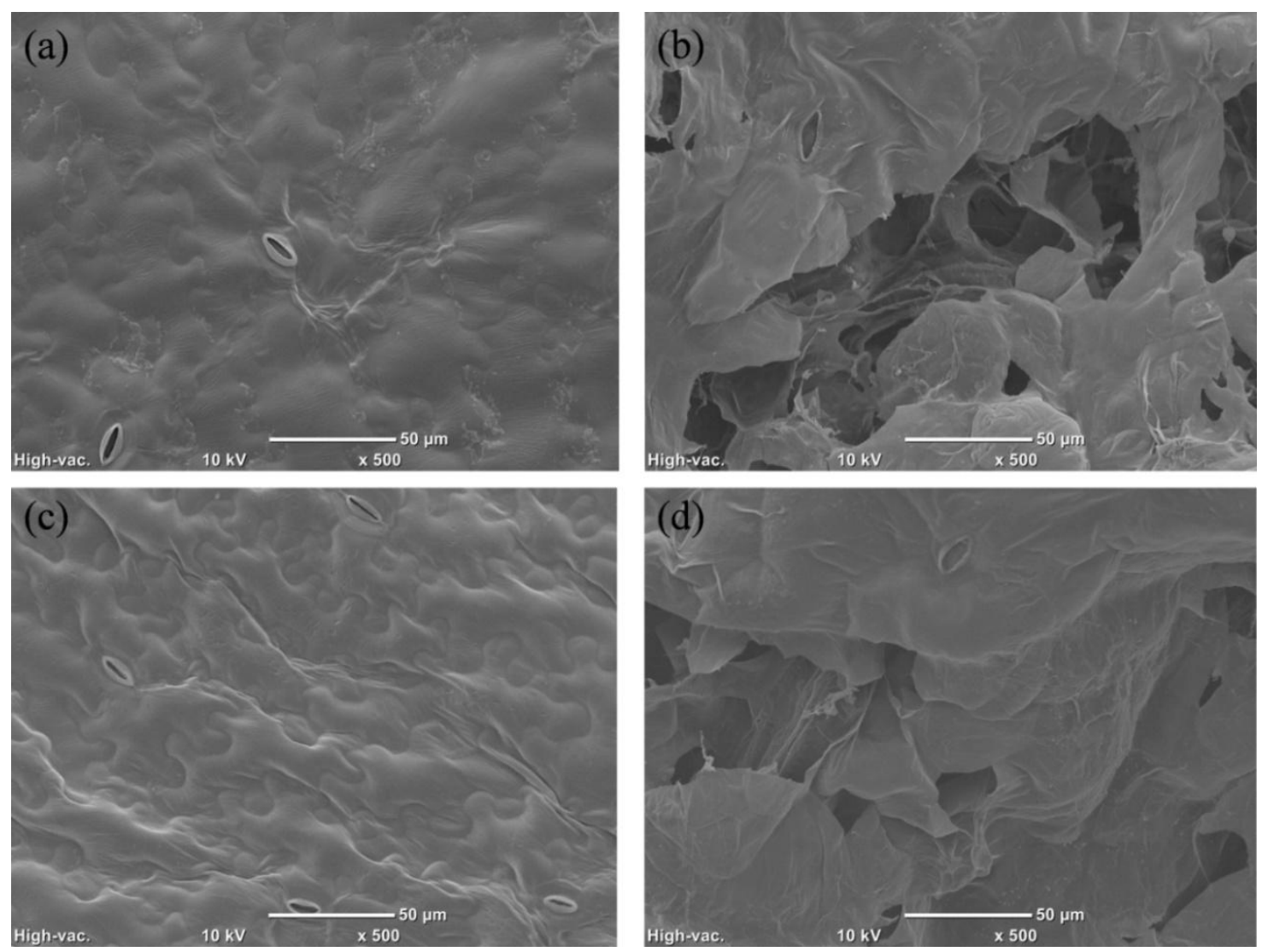

Figure 3.5 Scanning electron micrograph of the leaf surfaces of the lettuce before (a) and after (b) enzymatic digestion. Scanning electron micrograph of the leaf surfaces of the spinach before (c) and after (d) enzymatic digestion. The samples were treated with pectinase and cellulase and mixed for 10 s followed by incubation of 1.5 hours.

\subsection{Conclusions}

After the optimization of the condition of the enzymatic digestion, the $\mathrm{pH}$ of the buffer was selected as pH7.4 and the time of the enzymatic digestion was determined as 1.5 hours. The combination of the enzymes used for the digestion of spinach and lettuce was $22.5 \mathrm{U} / \mathrm{g}$ pectinase and $7.5 \mathrm{U} / \mathrm{g}$ cellulase and $7.5 \mathrm{U} / \mathrm{g}$ pectinase and $2.5 \mathrm{U} / \mathrm{g}$ cellulase, respectively. The physical 
appearance and SEM image before and after the enzymatic digestion further proved that the enzymatic reaction condition used in the experiment was able to achieve a relatively complete digestion result. 


\section{CHAPTER 4}

\section{SALMONELLA RECOVERY AFTER ENZYMATIC DIGESTION AND THE COMPARISON WITH STOMACHING AND MANUALLY SHAKING}

\subsection{Introduction}

Most bacteria contaminated the food matrix are attached to the surface or internalize in the tissue of the plants. There were many researches that proved pathogenic bacteria have the potential to internalize within the food matrix which makes the bacterial separation difficult. There are increased numbers of outbreaks associated with fresh produce over the past two decades. It is very important to develop an efficient method to separate bacteria strong attached and internalized within the food matrix. Otherwise we may get a false negative result if not all of the bacteria were separated into the buffer. The current methods used to isolate bacteria from leafy green vegetables are physical methods, such as blending, stomaching and manually shaking. However there are some concerns about the efficiency of the bacterial separation using these methods because the internalized bacteria are not able to be separated. The strategy we used here was able to digest the leafy green vegetables and break down the structure of the leaves, releasing the internalized bacteria. The recovery of Salmonella from the spinach and lettuce after enzymatic digestion was compared with other methods.

\subsection{Materials and Methods}

\subsubsection{Preparation of inocula}

Stock cultures of Salmonella enterica subsp. (ATCC 14028) were purchased from the American Type Culture Collection (ATCC; VA, USA) and stored in $-80^{\circ} \mathrm{C}$ freezer and used for all the inoculated experiments. The pure culture of Salmonella was grown in tryptone soya broth (TSB; Oxoid, Basingstoke, England) at $37^{\circ} \mathrm{C}$ overnight (18-20 hours) at $200 \mathrm{rpm}$ in an agitating incubator (Thermo Scientific, MA, USA). Approximately $10^{9} \mathrm{CFU} / \mathrm{mL}$ Salmonella were obtained 
from the incubation and the concentration was determined by enumeration after serial dilution and plating on Hektoen enteric agar (HE agar; Difco, NJ, USA) after incubation of 24 hours at $37^{\circ} \mathrm{C}$. Meanwhile, the original $\sim 10^{9} \mathrm{CFU} / \mathrm{mL}$ Salmonella was serially diluted to the desired concentration in 1x PBS buffer (phosphate buffered saline, $\mathrm{pH} 7.2,137.0 \mathrm{mM} \mathrm{NaCl}, 2.7 \mathrm{mM}$ $\left.\mathrm{KCl}, 10.0 \mathrm{mM} \mathrm{Na}_{2} \mathrm{HPO}_{4}, 2.0 \mathrm{mM} \mathrm{KH} \mathrm{PO}_{4}\right)$.

\subsubsection{Salmonella viability study}

The concentrations of pectinase and cellulase used to digest lettuce and spinach were investigated about their effect on the viability of Salmonella. The enzymatic digestion of lettuce and spinach was conducted in the PBS buffer, we therefore investigate if the enzyme will affect the viability of Salmonella in $2 \times$ PBS buffer. One hundred microliters of a Salmonella culture (approximately $10^{4} \mathrm{CFU} / \mathrm{mL}$ ) was inoculated into $9.9 \mathrm{~mL}$ of PBS with the combination of enzymes used in the digestion including: $7.5 \mathrm{U} / \mathrm{mL}$ pectinase and $2.5 \mathrm{U} / \mathrm{mL}$ cellulase, and 22.5 $\mathrm{U} / \mathrm{mL}$ pectinase and $7.5 \mathrm{U} / \mathrm{mL}$ cellulase. PBS buffer without added enzymes was also inoculated with the same concentration of Salmonella and used as the experimental control. The culture tubes were shaken in the incubator at $37{ }^{\circ} \mathrm{C}$ for 1.5 hours. Then the cultures were serially diluted and plated on selective HE agar. After incubation of the plates at $37{ }^{\circ} \mathrm{C}$ for 24 hours, the concentration of the Salmonella was determined. The results were compared with the negative control (no enzyme) after incubation of 1.5 hours to determine if the viability of Salmonella was affected by the levels of pectinase and cellulase used in the experiments.

\subsubsection{Inoculation of the produce and sample preparation}

One hundred microliters of Salmonella culture (approximate $10^{6} \mathrm{CFU} / \mathrm{mL}$ ) was spot inoculated on the surface of $10 \mathrm{~g}$ of spinach and lettuce leaves, respectively, by depositing $5 \mu \mathrm{L}$

droplets at 20 random locations to obtain $10^{5} \mathrm{CFU} / 10 \mathrm{~g}$ leaves. Spot inoculation was used to inoculate Salmonella, allowing a known number of bacterial cells applied on the surface of leaves and was shown to provide reproducible results $(4,24)$. Then the leaves were dried for 1 hour in a 
biosafety cabinet at $23^{\circ} \mathrm{C}$ to allow for the surface attachment of Salmonella. After inoculation, six portions of 10 gram samples were placed into $90 \mathrm{~mL}$ of $2 \mathrm{x}$ PBS buffer (pH 7.4) with the predetermined combination of enzymes resulted from the enzyme optimization work conducted previously $(7.5 \mathrm{U} / \mathrm{mL}$ pectinase and $2.5 \mathrm{U} / \mathrm{mL}$ cellulase for lettuce; $22.5 \mathrm{U} / \mathrm{mL}$ pectinase and 7.5 $\mathrm{U} / \mathrm{mL}$ cellulase for spinach) and mixed for 10 seconds at speed 2 ( 2 strokes per second). Traditional sample preparation methods of stomaching and manually mixing were compared. For the stomaching group, inoculated samples were placed in $90 \mathrm{~mL}$ of $2 \mathrm{x}$ PBS buffer without enzymes and stomached in a paddle mixer for 60 seconds at speed 4 (4 strokes per second). For the shaking group, the inoculated samples were placed in $90 \mathrm{~mL}$ of $2 \mathrm{x}$ PBS buffer without enzymes and manually shaken in the bag 25 times left-to-right and 25 times front-to-back. Then all the samples were incubated for 1.5 hours at $37^{\circ} \mathrm{C}$. The experiment was based on six independent trails.

\subsubsection{Immunomagnetic separation and microbiological studies}

Following enzyme digestion, $1 \mathrm{~mL}$ of the liquefied sample was taken out from the bag and used to determine the extracted Salmonella concentration. Twenty microliters of antiSalmonella magnetic beads (Life technology, Oslo, Norway) was added into each sample tube and incubated on a rotator for 30 minutes at $23^{\circ} \mathrm{C}$. The beads and captured Salmonella were then

magnetically separated using a strong separation magnet (IMagnet $\left.{ }^{\mathrm{TM}} ; \mathrm{BD}, \mathrm{NJ}, \mathrm{USA}\right)$ and washed three times using PBS buffer with $0.05 \%$ Tween-20 according to the manufacturer's instructions. The specificity and capture efficiency of the anti-Salmonella magnetic beads were confirmed by our previous study(55). The cleaned concentrated sample was then suspended in $1 \mathrm{~mL}$ of $1 \times$ PBS and the sample was plated on $\mathrm{HE}$ agar in $100 \mu \mathrm{L}$ aliquots. Plate counts were performed on the samples following incubation for 24 hours at $37^{\circ} \mathrm{C}$. The recovery efficiencies of Salmonella using three separation methods were determined. The percentage of the recovery of Salmonella was then determined by calculating the concentration of Salmonella after each treatment divided by 
the initial concentration of Salmonella inoculated on the leaves. A blank sample (uninoculated spinach and lettuce with enzymatic digestion) was conducted to confirm that there was no Salmonella present on the uninoculated produce.

\subsubsection{Statistical Analysis.}

Data were analyzed by ANOVA using SAS software (SAS Institute, Inc., Cary, NC). Tukey's HSD test was used to determine the significant differences of mean values. A "p value" of less than 0.05 was considered statistically significant. The data presented represents a mean of a minimum of three independent samples and error bars represent the standard deviation of the replicates.

\subsection{Results and discussion}

\subsubsection{The effect of enzyme on the viability of Salmonella}

The enzyme combinations used to digest spinach and lettuce were optimized above ( 7.5 $\mathrm{U} / \mathrm{g}$ pectinase and $2.5 \mathrm{U} / \mathrm{g}$ cellulase for lettuce and $22.5 \mathrm{U} / \mathrm{mL}$ pectinase and $7.5 \mathrm{U} / \mathrm{mL}$ cellulase for spinach). After the determination of the optimized combination of pectinase and cellulase used in the digestion, the effect of the enzyme selected for the enzymatic digestion needed to be confirmed not to influence the viability of Salmonella. The digestion of the plant components might result in the addition of some inhibitor or antimicrobial compounds into the soluble portion of the sample. If these components had a negative effect on bacterial viability, the assay could result in a false-negative. Therefore, it was important that the selected levels of enzymes for the digestion (pectinase and cellulase) did not affect the viability of the Salmonella inoculated on the spinach and lettuce in PBS buffer (49).

Some studies have found that the extracts of fresh produce such as lettuce, perilla leaves and cucumber had no significant antimicrobial activity $(30,51)$. In order to determine that the enzyme digestion had no significant effect on bacterial viability, controls were run with Salmonella confirming that the concentrations of pectinase and cellulase for digesting both lettuce 
and spinach had no significance effect $(\mathrm{P}>0.05)$ on the viability of Salmonella (Figure 4.1). The results confirmed that the enzymes used in the experiment had no significant effect on the viability of Salmonella in PBS buffer. Overall, the enzyme concentration $7.5 \mathrm{U} / \mathrm{mL}$ pectinase and $2.5 \mathrm{U} / \mathrm{mL}$ cellulase for lettuce and $22.5 \mathrm{U} / \mathrm{mL}$ pectinase and $7.5 \mathrm{U} / \mathrm{mL}$ cellulase for spinach had no significantly affect the viability of Salmonella. Therefore, when we applied the enzymatic digestion to the separation of Salmonella from the leaves, the number of Salmonella on the leaves was not influenced by the enzyme which can ensure an accurate result.

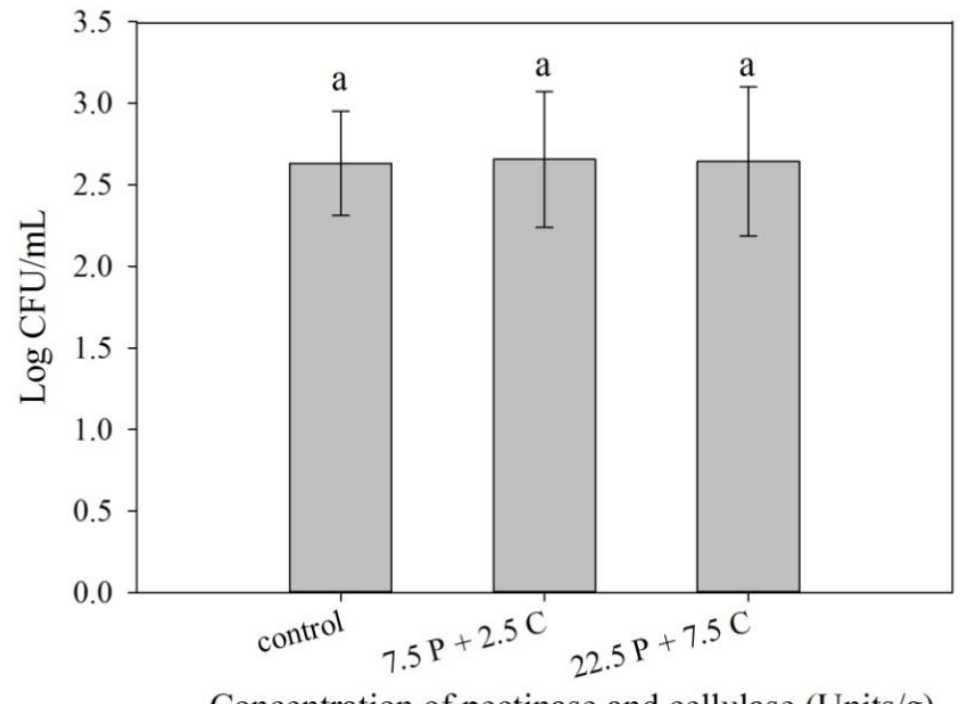

Concentration of pectinase and cellulase (Units/g)

Figure 4.1 The number of Salmonella inoculated in $2 \times \mathrm{PBS}(\mathrm{pH} 7.4)$ with the combination of enzyme used to digest lettuce or spinach as well as the control (no enzyme) after incubation of 1.5 hours at $37{ }^{\circ} \mathrm{C}$. Bars with same letter are not significantly different $(\mathrm{P}>0.05)$. The error bars represent the standard deviation of three measurements.

\subsubsection{Salmonella recovery on spinach and lettuce after enzymatic digestion}

The effect of enzymatic digestion on bacteria separation from the leafy green vegetables was investigated. Enzyme digestion of spinach and lettuce was used to break down the tissue of the plants and release the bacteria from the leaves into the buffer. After the enzyme digestion of 
the leaves, immunomagnetic separation was employed which was able to separate a broad range of bacteria from a complex liquid sample into a relatively clean sample without the debris from the leaves. After plating on selective medium followed by enumeration of Salmonella, the recovery of Salmonella was calculated and compared between the enzymatic digestion method and the other two common bacterial separation methods, stomaching and manually shaking. The results suggested that the recovery of the Salmonella from both lettuce and spinach using enzymatic digestion was significantly higher $(\mathrm{P}<0.05)$ than the other two methods, with approximately twice of that using stomaching or shaking (Figure 4.2). In the present study, the enzyme treated samples had a $74.2 \pm 8.20 \%$ and $78.4 \pm 9.94 \%$ recovery of Salmonella for spinach and lettuce respectively. After stomaching the recovery of Salmonella was $40.9 \pm 7.81 \%$ from spinach and $43.7 \pm 10.01 \%$ from lettuce. The recovery of Salmonella after manually shaking was $32.4 \pm 6.91 \%$ and $31.5 \pm 6.81 \%$ for lettuce and spinach, respectively. This indicated that the enzymatic digestion was more effective than other physical method such as stomaching or shaking. Pectinase and cellulase were able to aid in the release of Salmonella into the buffer, resulting in a more efficient separation. In these experiments, both spinach and lettuce were digested to small pieces and the cell walls of the leaves were broken down which could not be easily accomplished by simple physical methods. 


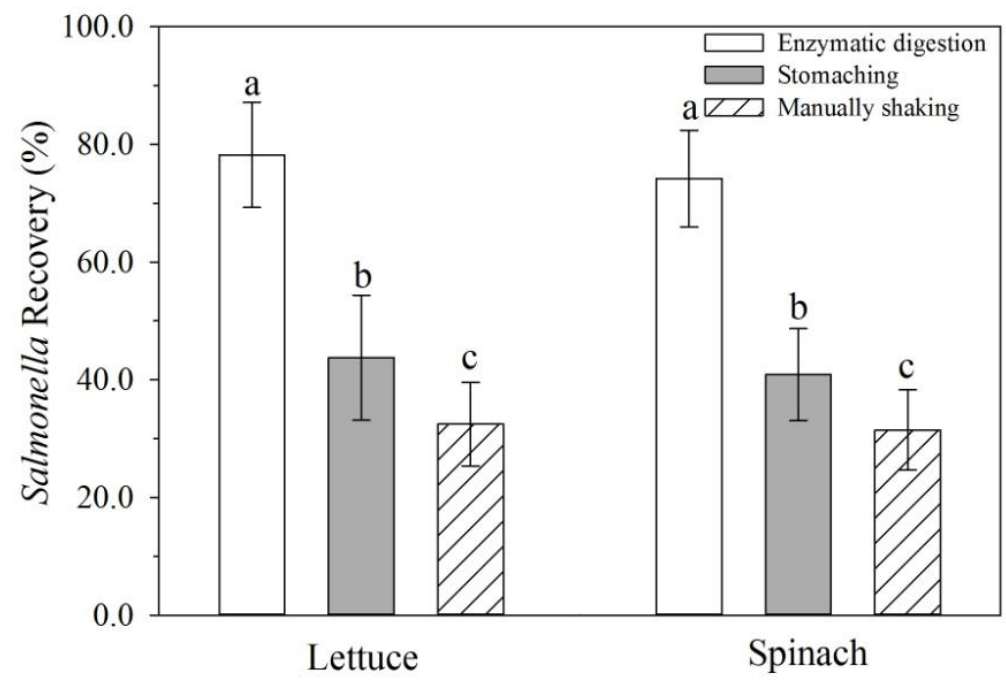

Figure 4.2 The recovery of the Salmonella separated from the lettuce and spinach, respectively after three different separation methods of bacteria. The white bar represents the recovery of Salmonella after homogenization of $10 \mathrm{~s}$ and enzymatic digestion for 1.5 hours. The grey bars represent the recovery of Salmonella after stomaching for 1 minute. The white bars with oblique lines represent the recovery of Salmonella after manually shaking. Bars with different letters (a, b or c) are significantly different $(\mathrm{P}<0.05)$ among the groups.

When results of lettuce were compared to those of spinach, we can observe that there was no significant difference $(\mathrm{P}>0.05)$ in Salmonella recovery between the two produce types within the same treatment. The number of Salmonella recovered from spinach was slightly lower than that from lettuce most likely due to the differences in the method of attachment and plant constituents. The bacterial recovery varies according to different sample preparations as well as the type of the microorganism and food matrix (50). For example, it was previously found that the strength of Salmonella adhesion on romaine lettuce is significantly higher than on cabbage (40). Because the components that constitute each food matrix are different and the separation method 
is the link between the complex food matrix and the detection, it is most likely that each food sample will require a customized protocol for separation and concentration.

Bacterial separation is an essential part of the sample preparation which affects the accuracy of downstream detection, and is therefore very important for monitoring potential food safety hazards. A poor recovery of target bacteria will cause an underestimation of bacterial contamination, increasing the potential of the occurrence of a foodborne pathogen outbreak. There are many methods currently used to separate bacteria from the solid food matrix, such as rinsing, blending and stomaching. Studies on the comparison of different sample preparation methods involving bacterial separation were conducted by numerous researchers. Kase et al. compared the soaking, blending and stomaching method to isolate E. coli from leafy greens and found that soaking and stomaching were significantly more effective $(\mathrm{P}<0.05)$ than blending $(7)$. Other preparation methods, i.e pummeling, pulsifying, stomaching, and shaking by hand were compared by $\mathrm{Wu}$ and $\mathrm{Kim}$ for bacterial recovery and ranged from $25 \%$ to $50 \%(34,61)$. Their results suggested that a powerful mechanical treatment resulted in a better recovery of microorganisms. In our study, stomaching, manually shaking and enzymatic digestion were compared for achieving the maximum recovery of Salmonella from spinach and lettuce. According to FDA Bacteriological Analytical Manual, the sample preparation of leafy green vegetables is manually mixing of the contents by vigorously swirling (2), but it has been demonstrated that manually shaking is not always effective when the bacteria have strong adhesion to the produce (16). Our results demonstrated that enzymatic digestion showed advantage in the improvement of bacterial separation over stomaching and shaking. It has the potential to be applied to the common leafy green vegetables.

\subsection{Conclusions}

The results confirmed that the enzyme concentration $7.5 \mathrm{U} / \mathrm{mL}$ pectinase and $2.5 \mathrm{U} / \mathrm{mL}$ cellulase for lettuce and $22.5 \mathrm{U} / \mathrm{mL}$ pectinase and $7.5 \mathrm{U} / \mathrm{mL}$ cellulase for spinach had no 
significant effect on the viability of Salmonella. The recovery of Salmonella from spinach and lettuce after enzymatic digestion was determined and compared with that after stomaching and manually shaking. These results showed that the recovery of Salmonella of the enzyme treated samples was $74.2 \%$ and $88.4 \%$ for spinach and lettuce respectively. The recovery of Salmonella after stomaching was $40.9 \%$ from spinach and $43.7 \%$ from lettuce. The recovery of Salmonella after manually shaking was $32.4 \%$ and $31.5 \%$ for lettuce and spinach, respectively. The results demonstrated that the recovery of Salmonella after enzymatic digestion was significantly higher than that after stomaching and manually shaking, proving that enzymatic digestion was an effective method to help improve bacterial separation. 


\section{CHAPTER 5}

\section{SUMMARY AND CONCLUSIONS}

In summary, a novel and effective method to improve the bacterial separation from the food matrices using enzymatic digestion followed by immunomagnetic separation was developed. This research demonstrated that an optimal combination of pectinase and cellulase will provide an effective digestion for lettuce and spinach. The optimum concentration of enzyme to digest lettuce was $7.5 \mathrm{U} / \mathrm{g}$ pectinase and $2.5 \mathrm{U} / \mathrm{g}$ cellulase and the concentration was $22.5 \mathrm{U} / \mathrm{g}$ pectinase and 7.5 U/g cellulase for spinach. The combination of enzyme treatment was able to break down the whole leaves of spinach and lettuce significantly and achieve a liquefied sample, resulting in the detachment of Salmonella from spinach and lettuce. Therefore, Salmonella from the leaves was released into the buffer when the leaves were digested and the food samples became liquefied and more homogeneous. The second step involved the removal of Salmonella from the digested and liquefied sample using anti-Salmonella magnetic beads was able to easily achieve the separation without interfering compounds. The results from this study indicate that a higher recovery of Salmonella can be achieved through use of enzyme digestion and IMS compared to traditional methods of stomaching and manually shaking.

The addition of an enzyme digestion step resulted in a significant improvement in the separation of Salmonella from lettuce and spinach. The strategy of using enzyme digestion prior to a separation step should be explored for other food matrices, such as meat and dairy and applied for the separation of additional pathogens. An efficient sample treatment method will improve the sensitivity of conventional microbiological methods and facilitate the rapid detection of bacteria. 


\section{APPENDIX}

\section{SUPPLEMENTRARY TABLE}

\begin{tabular}{|c|c|c|c|c|c|c|c|c|c|}
\hline \multirow{2}{*}{$\begin{array}{l}\text { Leafy green } \\
\text { vegetables } \\
\text { Lettuce }\end{array}$} & \multicolumn{9}{|c|}{ Concentration of enzyme [Units/g] } \\
\hline & Pectinase & 0 & 1.5 & 3.0 & 5.0 & 7.5 & 10.0 & 15.0 & 20.0 \\
\hline & Cellulase & 0 & 1.5 & 3.0 & 5.0 & 7.5 & 10.0 & 15.0 & 20.0 \\
\hline & $\begin{array}{c}\text { Pectinase } \\
+\end{array}$ & 7.5 & 7.5 & 7.5 & 7.5 & & & & \\
\hline & Cellulase & 1.5 & 2.5 & 5.0 & 7.5 & & & & \\
\hline \multirow[t]{4}{*}{ Spinach } & Pectinase & 0 & 5.0 & 7.5 & 10.0 & 15.0 & 20.0 & 25.0 & 30.0 \\
\hline & Cellulase & 0 & 5.0 & 7.5 & 10.0 & 15.0 & 20.0 & 25.0 & 30.0 \\
\hline & $\begin{array}{c}\text { Pectinase } \\
+\end{array}$ & 22.5 & 22.5 & 22.5 & 22.5 & & & & \\
\hline & Cellulase & 5.0 & 7.5 & 10.0 & 15.0 & & & & \\
\hline
\end{tabular}

Table 1 The combinations of pectinase and cellulase used for the digestion of lettuce and spinach, respectively. The enzymes were aimed to digest $10 \mathrm{~g}$ of leaves in $90 \mathrm{~mL}$ PBS buffer. 


\section{BIBLIOGRAPHY}

1. Alocilja, E. C., and S. M. Radke. 2003. Market analysis of biosensors for food safety. Biosensors and Bioelectronics. 18:841-846.

2. Andrews, W. H., A. Jacobson, and T. Hammack. 2014. Bacteriological Analytical Manual Chapter 5 Salmonella. Available at:

http://www.fda.gov/Food/FoodScienceResearch/LaboratoryMethods/ucm070149.htm. Date Accessed, May 2014.

3. Berensmeier, S. 2006. Magnetic particles for the separation and purification of nucleic acids. Applied microbiology and biotechnology. 73:495-504.

4. Beuchat, L. R., J. M. Farber, E. H. Garrett, L. J. Harris, M. E. Parish, T. V. Suslow, and F. F. Busta. 2001. Standardization of a method to determine the efficacy of sanitizers in inactivating human pathogenic microorganisms on raw fruits and vegetables. Journal of Food Protection. 64:1079-1084.

5. Brandl, M. 2008. Plant lesions promote the rapid multiplication of Escherichia coli O157: H7 on postharvest lettuce. Applied and environmental microbiology. 74:5285-5289.

6. Brehm-Stecher, B., C. Young, L. A. Jaykus, and M. L. Tortorello. 2009. Sample Preparation: The Forgotten Beginning. Journal of Food Protection. 72:1774-1789.

7. Burnett, A. B., and L. R. Beuchat. 2001. Comparison of sample preparation methods for recovering Salmonella from raw fruits, vegetables, and herbs. Journal of Food Protection. 64:1459-1465.

8. Caffall, K. H., and D. Mohnen. 2009. The structure, function, and biosynthesis of plant cell wall pectic polysaccharides. Carbohydrate research. 344:1879-1900.

9. Center for Science in the Public Interest. 2014. Outbreak alert. A review of foodborne illness in America from 2002-2011. Available at: http://cspinet.org/reports/outbreakalert2014.pdf. Date Accessed, April 2014. 
10. Centers for Disease Control and Prevention. 2015. Foodborne Diseases Active Surveillance Network (FoodNet): FoodNet Surveillance Report for 2013. Available at: http://www.cdc.gov/foodnet/reports/annual-reports-2013.html. Date Accessed, December 2015.

11. Chemburu, S., E. Wilkins, and I. Abdel-Hamid. 2005. Detection of pathogenic bacteria in food samples using highly-dispersed carbon particles. Biosensors and Bioelectronics. 21:491-499.

12. Chen, J., S. D. Alcaine, Z. Jiang, V. M. Rotello, and S. R. Nugen. 2015. Detection of Escherichia coli in Drinking Water Using T7 Bacteriophage-Conjugated Magnetic Probe. Analytical Chemistry. 87:8977-8984.

13. Chen, J., B. Duncan, Z. Wang, L.-S. Wang, V. M. Rotello, and S. R. Nugen. 2015. Bacteriophage-based nanoprobes for rapid bacteria separation. Nanoscale. 7:16230-16236.

14. Coburn, B., G. A. Grassl, and B. B. Finlay. 2006. Salmonella, the host and disease: a brief review. Immunol Cell Biol. 85:112-118.

15. Cosgrove, D. J. 2005. Growth of the plant cell wall. Nature reviews molecular cell biology. 6:850-861.

16. Deering, A. J., L. J. Mauer, and R. E. Pruitt. 2012. Internalization of E. coli O157:H7 and Salmonella spp. in plants: A review. Food Research International. 45:567-575.

17. Doyle, M. P., and M. C. Erickson. 2008. Summer meeting 2007 - the problems with fresh produce: an overview. Journal of Applied Microbiology. 105:317-330.

18. Eblen, B. S., M. O. Walderhaug, S. Edelson-Mammel, S. J. Chirtel, A. De Jesus, R. I. Merker, R. L. Buchanan, and A. J. Miller. 2004. Potential for internalization, growth, and survival of Salmonella and Escherichia coli 0157 : H7 in oranges. Journal of Food Protection. 67:1578-1584. 
19. Erickson, M. C. 2012. Internalization of fresh produce by foodborne pathogens. Annual review of food science and technology. 3:283-310.

20. Flint, J. A., Y. T. Van Duynhoven, F. J. Angulo, S. M. DeLong, P. Braun, M. Kirk, E. Scallan, M. Fitzgerald, G. K. Adak, and P. Sockett. 2005. Estimating the burden of acute gastroenteritis, foodborne disease, and pathogens commonly transmitted by food: an international review. Clinical Infectious Diseases. 41:698-704.

21. Fothergill, A., V. Kasinathan, J. Hyman, J. Walsh, T. Drake, and Y. F. W. Wang. 2013. Rapid identification of bacteria and yeasts from positive-blood-culture bottles by using a lysis-filtration method and matrix-assisted laser desorption ionization-time of flight mass spectrum analysis with the SARAMIS database. Journal of clinical microbiology. 51:805809.

22. Froder, H., C. G. Martins, K. L. O. de Souza, M. Landgraf, B. D. G. M. Franco, and M. T. Destro. 2007. Minimally processed vegetable salads: Microbial quality evaluation. Journal of Food Protection. 70:1277-1280.

23. Fukushima, H., K. Katsube, Y. Hata, R. Kishi, and S. Fujiwara. 2007. Rapid separation and concentration of food-borne pathogens in food samples prior to quantification by viable-cell counting and real-time PCR. Applied and Environmental Microbiology. 73:92-100.

24. Fustier, P., A. Lafond, C. P. Champagne, and F. Lamarche. 1998. Effect of inoculation techniques and relative humidity on the growth of molds on the surfaces of yellow layer cakes. Applied and Environmental Microbiology. 64:192-196.

25. Gómez-López, V. M., A. Marín, A. Allende, L. R. Beuchat, and M. I. Gil. 2013. Postharvest handling conditions affect internalization of Salmonella in baby spinach during washing. Journal of Food Protection. 76:1145-1151.

26 Greer, G. G. 2005. Bacteriophage control of foodborne bacteria. Journal of Food Protection. 68:1102-1111. 
27. International Commission on Microbiological Specifications for Foods. 1996. Salmonella spp. p. 217-265. In, Microorganisms in foods. 5, Characteristics of microbial pathogens. Blackie Academic \& Professional.

28. Irvine, W. N., I. A. Gillespie, F. B. Smyth, P. J. Rooney, A. McClenaghan, M. J. Devine, V. K. Tohani, and O. C. Team. 2009. Investigation of an outbreak of Salmonella enterica serovar Newport infection. Epidemiology and Infection. 137:1449-1456.

29. Itoh, Y., Y. Sugita-Konishi, F. Kasuga, M. Iwaki, Y. Hara-Kudo, N. Saito, Y. Noguchi, H. Konuma, and S. Kumagai. 1998. Enterohemorrhagic Escherichia coli O157 : H7 present in radish sprouts. Applied and Environmental Microbiology. 64:1532-1535.

30. Jacobson, A. P., V. S. Gill, K. A. Irvin, H. Wang, and T. S. Hammack. 2012. Evaluation of methods to prepare samples of leafy green vegetables for preenrichment with the Bacteriological Analytical Manual Salmonella Culture Method. Journal of Food Protection. 75:400-404.

31. Janes, M. E., K. S. Kim, and M. G. Johnson. 2005. Transmission electron microscopy study of enterohemorrhagic Escherichia coli $\mathrm{O} 157$ : H7 in apple tissue. Journal of Food Protection. 68:216-224.

32. Kaclíková, E., T. Kuchta, H. Kay, and D. Gray. 2001. Separation of Listeria from cheese and enrichment media using antibody-coated microbeads and centrifugation. Journal of microbiological methods. 46:63-67.

33. Kase, J. A., A. Maounounen-Laasri, I. Son, D. M. Deer, S. Borenstein, S. Prezioso, and T. S. Hammack. 2012. Comparison of different sample preparation procedures for the detection and isolation of Escherichia coli O157:H7 and Non-O157 STECs from leafy greens and cilantro. Food Microbiology. 32:423-426. 
34. Kim, S. R., Y. Yoon, W. I. Kim, K. H. Park, H. J. Yun, D. H. Chung, J. C. Yun, and K. Y. Ryu. 2012. Comparison of sample preparation methods for the recovery of foodborne pathogens from fresh produce. Journal of Food Protection. 75:1213-1218.

35. Kroupitski, Y., D. Golberg, E. Belausov, R. Pinto, D. Swartzberg, D. Granot, and S. Sela. 2009. Internalization of Salmonella enterica in leaves is induced by light and involves chemotaxis and penetration through open stomata. Applied and environmental microbiology. 75:6076-6086.

36. Lazcka, O., F. J. Del Campo, and F. X. Munoz. 2007. Pathogen detection: A perspective of traditional methods and biosensors. Biosensors and Bioelectronics. 22:1205-1217.

37. Mason, T., E. Joyce, S. Phull, and J. Lorimer. 2003. Potential uses of ultrasound in the biological decontamination of water. Ultrasonics sonochemistry. 10:319-323.

38. Mohnen, D. 2008. Pectin structure and biosynthesis. Current opinion in plant biology. 11:266-277.

39. Nugen, S. R., and A. J. Baeumner. 2008. Trends and opportunities in food pathogen detection. Analytical and Bioanalytical Chemistry. 391:451-454.

40. Patel, J., and M. Sharma. 2010. Differences in attachment of Salmonella enterica serovars to cabbage and lettuce leaves. International Journal of Food Microbiology. 139:41-47.

41. Pui, C. F., W. C. Wong, L. C. Chai, T. Robin, J. Ponniah, M. Sahroni, N. Hidayah, U. Anyi, F. Mohamad Ghazali, and Y. K. Cheah. 2011. Salmonella: A foodborne pathogen. International Food Research Journal. 18:465-473.

42. Rodrigues-Szulc, U. M., G. Ventoura, B. M. Mackey, and M. J. Payne. 1996. Rapid physicochemical detachment, separation and concentration of bacteria from beef surfaces. Journal of Applied Bacteriology. 80:673-681.

43. Salam, F., and I. E. Tothill. 2009. Detection of Salmonella typhimurium using an electrochemical immunosensor. Biosensors and Bioelectronics. 24:2630-2636. 
44. Saldafia, Z., E. Sa'nchez, J. XicohtencatI-Cortes, J. L. Puente, and J. A. Girón. 2011. Surface structures involved in plant stomata and leaf colonization by Shiga-toxigenic Escherichia coli O157: H7. Front Microbiol. 2:119.

45. Scheller, H. V., J. K. Jensen, S. O. Sørensen, J. Harholt, and N. Geshi. 2007. Biosynthesis of pectin. Physiologia plantarum. 129:283-295.

46. Schlundt, J. 2002. New directions in foodborne disease prevention. International Journal of Food Microbiology. 78:3-17.

47. Sharpe, A., and A. Jackson. 1972. Stomaching: a new concept in bacteriological sample preparation. Applied microbiology. 24:175-178.

48. Squirrell, D., R. Price, and M. Murphy. 2002. Rapid and specific detection of bacteria using bioluminescence. Analytica Chimica Acta. 457:109-114.

49. Stevens, K. A., and L.-A. Jaykus. 2004. Bacterial separation and concentration from complex sample matrices: A Review. Critical Reviews in Microbiology. 30:7-24.

50. Takeuchi, K., C. M. Matute, A. N. Hassan, and J. F. Frank. 2000. Comparison of the attachment of Escherichia coli $\mathrm{O} 157$ : H7, Listeria monocytogenes, Salmonella typhimurium, and Pseudomonas fluorescens to lettuce leaves. Journal of Food Protection. 63:1433-1437.

51. U.S. Food and Drug Administration. 2001. Analysis and evaluation of preventive control measures for the control and reduction/elimination of microbial hazards on fresh-cut produce. Available at:

http://www.fda.gov/Food/FoodScienceResearch/SafePracticesforFoodProcesses/ucm091016. htm. Date Accessed, June 2009.

52. Uyttendaele, M., I. Van Hoorde, and J. Debevere. 2000. The use of immuno-magnetic separation (IMS) as a tool in a sample preparation method for direct detection of $L$. monocytogenes in cheese. International journal of food microbiology. 54:205-212. 
53. Velusamy, V., K. Arshak, O. Korostynska, K. Oliwa, and C. Adley. 2010. An overview of foodborne pathogen detection: in the perspective of biosensors. Biotechnol Adv. 28:232-54.

54. Voragen, A. G. J., G. J. Coenen, R. P. Verhoef, and H. A. Schols. 2009. Pectin, a versatile polysaccharide present in plant cell walls. Structural Chemistry. 20:263-275.

55. Wang, D. H., Z. Y. Wang, J. H. Chen, A. J. Kinchla, and S. R. Nugen. 2016. Rapid detection of Salmonella using a redox cycling-based electrochemical method. Food Control. 62:81-88.

56. Wang, H., H. Feng, W. Liang, Y. Luo, and V. Malyarchuk. 2009. Effect of surface roughness on retention and removal of Escherichia coli $\mathrm{O} 157: \mathrm{H} 7$ on surfaces of selected fruits. Journal of Food Science. 74:E8-E15.

57. Wang, Z., D. Wang, J. Chen, D. A. Sela, and S. R. Nugen. 2016. Development of a novel bacteriophage based biomagnetic separation method as an aid for sensitive detection of viable Escherichia coli. Analyst. 141:1009-1016.

58. Warriner, K., S. Spaniolas, M. Dickinson, C. Wright, and W. M. Waites. 2003. Internalization of bioluminescent Escherichia coli and Salmonella Montevideo in growing bean sprouts. Journal of Applied Microbiology. 95:719-727.

59. Willats, W. G., L. McCartney, W. Mackie, and J. P. Knox. 2001. Pectin: cell biology and prospects for functional analysis. p. 9-27. In, Plant Cell Walls Springer.

60. Wright, D., P. Chapman, and C. Siddons. 1994. Immunomagnetic separation as a sensitive method for isolating Escherichia coli $\mathrm{O} 157$ from food samples. Epidemiology and infection. $113: 31-39$

61. Wu, V. C., P. Jitareerat, and D. Y. Fung. 2003. Comparison of the pulsifier and the stomacher for recovering microorganisms in vegetables. Journal of Rapid Methods \& Automation in Microbiology. 11:145-152. 